\title{
The effect of erythropoietin on normal and neoplastic cells
}

\author{
This article was published in the following Dove Press journal: \\ Biologics:Targets and Therapy \\ 26 June 2012 \\ Number of times this article has been viewed
}

\author{
Steve Elliott \\ Angus M Sinclair \\ Oncology Research, Amgen, \\ Thousand Oaks, CA, USA
}

Correspondence: Angus M Sinclair Oncology Research, Amgen, I Amgen Center Drive, Thousand Oaks, CA 91362, USA

$\mathrm{Tel}+\mathrm{I} 8054477$ I 38

Fax + I 8053758524

Email anguss@amgen.com
Abstract: Erythropoietin (Epo) is an essential hormone that binds and activates the Epo receptor (EpoR) resident on the surface of erythroid progenitor cells, thereby promoting erythropoiesis. Recombinant human erythropoietin has been used successfully for over 20 years to treat anemia in millions of patients. In addition to erythropoiesis, Epo has also been reported to have other effects, such as tissue protection and promotion of tumor cell growth or survival. This became of significant concern in 2003, when some clinical trials in cancer patients reported increased tumor progression and worse survival outcomes in patients treated with erythropoiesisstimulating agents (ESAs). One of the potential mechanisms proffered to explain the observed safety issues was that functional EpoR was expressed in tumors and/or endothelial cells, and that ESAs directly stimulated tumor growth and/or antagonized tumor ablative therapies. Since then, numerous groups have performed further research evaluating this potential mechanism with conflicting data and conclusions. Here, we review the biology of endogenous Epo and EpoR expression and function in erythropoiesis, and evaluate the evidence pertaining to the expression of EpoR on normal nonhematopoietic and tumor cells.

Keywords: erythropoietin, erythropoietin receptor, tumor, anemia, angiogenesis

\section{Introduction}

Erythropoietin (Epo) is a hormone, so named because of early studies demonstrating that Epo had a singular effect on stimulation of erythropoiesis, the formation of red blood cells. ${ }^{1}$ Epo functions by binding to and activating the Epo receptor (EpoR) expressed on the surface of committed erythroid progenitor cells. This in turn induces erythroid progenitor cell survival, proliferation, and differentiation into circulating enucleated hemoglobin-containing red blood cells (RBCs), which are critical for oxygen transport.

The cloning of the EPO gene in the early 1980s allowed for the development of recombinant erythropoietins and analogs (erythropoiesis-stimulating agents [ESAs]), offering an alternative to transfusion as a method of raising hemoglobin levels in patients with anemia. However, in some clinical trials, the treatment of cancer patients with recombinant human Epo (rHuEpo) or other ESAs has been associated with decreased locoregional control of tumor growth and/or decreased survival. ${ }^{2,3}$ Some investigators have reported that ESAs may have nonhematopoietic effects via direct activation of EpoR on nonhematopoietic cells, including tumor cells. This hypothesis was used as one possible explanation for the decreased locoregional control of tumor and decreased survival reported in some ESA clinical trials in anemic cancer patients. 
In this review, we examine the mechanisms by which ESAs stimulate the formation of normal erythroid cells, and explore the hypothesis that ESAs can stimulate growth or survival of other nonhematopoietic cell types, including tumor cells.

\section{Erythropoiesis}

Maturing erythroid progenitor cells expand in number and decrease in size as they progress through a series of differentiation stages (Figure 1). The first committed erythroid cell type forms characteristic "burst" colonies in semisolid medium, and was therefore called a burst-forming unit-erythroid cell (BFU-E). BFU-E cells are present at $40-120$ cells per $10^{5}$ bone marrow cells, ${ }^{4}$ and further differentiate into colony-forming unit-erythroid (CFU-E) cells. CFU-E cells, present at concentrations of 200-600 cells per $10^{5}$ bone marrow cells, ${ }^{4}$ begin synthesis of hemoglobin and differentiate into erythroblasts. Erythroblasts enucleate forming reticulocytes, so named because of the "reticulin" associated with the residual ribosomal RNA detectable with dyes such as methylene blue. After several days, mitochondria are degraded, reticulin declines, and the cells become mature RBCs. RBCs lack DNA, and therefore can neither divide nor alter gene expression in response to stimuli. ${ }^{5}$

Erythropoiesis occurs in specialized niches in the bone marrow, encompassing a macrophage surrounded by maturing erythroid cells. ${ }^{6}$ In healthy humans, $2 \times 10^{11} \mathrm{RBCs}$ are generated per day and constitute $99 \%$ of circulating cells and approximately $40 \%-45 \%$ of the blood volume. To sustain this level of RBC production, a substantial fraction (25\%) of the cells in a normal bone marrow smear are erythroid precursors. ${ }^{7}$ However, erythroid precursors in the "liquid" portion of bone marrow represent a smaller proportion $(0.01 \%-1 \%){ }^{8-11}$ RBCs have a lifespan of 3-4 months under normal conditions in humans, ${ }^{12}$ but can be decreased in such disease states as renal failure. ${ }^{13}$

\section{Erythropoietin}

Erythropoiesis is stimulated when Epo, a glycoprotein hormone expressed primarily in the kidney, binds and activates

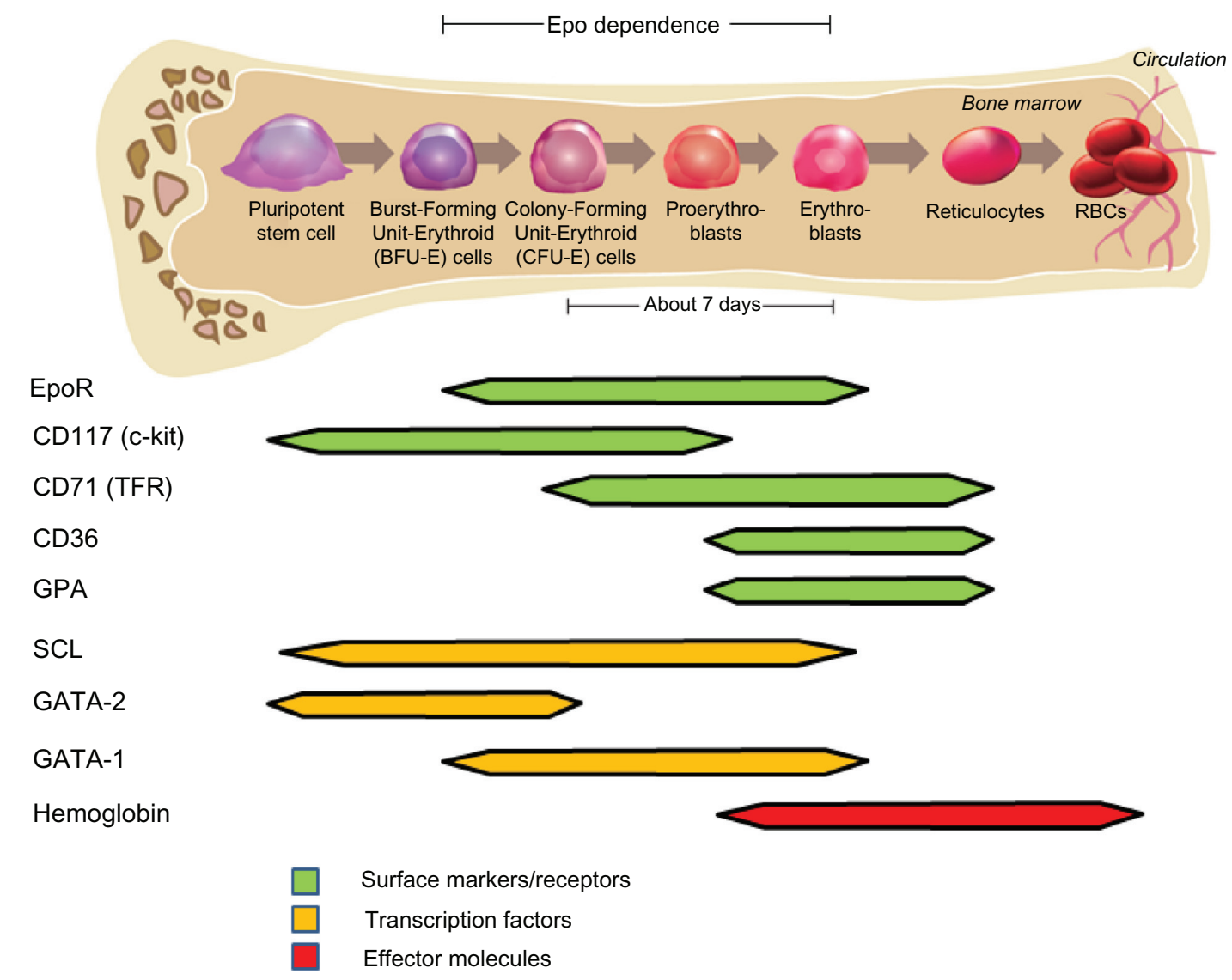

Figure I Erythropoiesis and the expression of stage-specific markers.

Notes: Shown is a schematic diagram of the various stages of human erythropoiesis that results in the formation of mature red blood cells (RBCs). Time-dependent expression of various proteins is shown, including erythropoietin receptor (EpoR) and other cell surface markers (green), transcription factors (orange), and effector molecules such as hemoglobin (red). 
the EpoR expressed on the surface of erythroid progenitor cells. HuEpo is encoded by a single gene on chromosome $7^{14}$ (mouse chromosome 5) that is transcribed into a 1.6-2.0 kb $\mathrm{mRNA}^{15}$ and translated into a 193 amino acid (aa) precursor protein. During transit through the secretory apparatus, the 27 aa signal peptide and C-terminal arginine are removed, carbohydrate chains are added ( $3 \mathrm{~N}$-linked and $1 \mathrm{O}$-linked) and the $\sim 30-\mathrm{kDa}$ glycoprotein is released into the surrounding fluids. This process occurs rapidly, and Epo does not typically accumulate intracellularly. ${ }^{16}$

The normal level of circulating Epo in humans is approximately $5 \mathrm{pM}(\sim 20 \mathrm{mU} / \mathrm{mL} ; 100 \mathrm{pg} / \mathrm{mL})$, substantially below the $\mathrm{K}_{\mathrm{d}}$ of the Epo-EpoR interaction $(\sim 100 \mathrm{pM})$, indicating that only a fraction of the EpoR is Epo bound under normal conditions. However, this level of binding is sufficient to sustain erythropoiesis at a rate that will maintain normal RBC levels. Increased Epo concentrations result in an increased rate of erythropoiesis, ${ }^{17-19}$ thereby resulting in an increase in circulating RBCs with a maximal rate of erythropoiesis achieved at Epo concentrations of approximately $0.5-1 \mathrm{U} / \mathrm{mL} \cdot{ }^{18,20}$ Low Epo concentrations, on the other hand, result in apoptosis of precursor cells. ${ }^{21}$ Epo concentrations below the normal circulating concentration therefore result in a decline in $\mathrm{RBC}$ numbers in peripheral blood because the rate of loss $(\sim 0.8 \%-1 \%$ per day) exceeds the rate of production.

Epo expression increases with decreasing oxygen tension (hypoxia), and this mechanism appears to be the primary driver of erythropoiesis. Hypoxia by itself has little effect on erythropoiesis in vitro. ${ }^{22}$ Hypoxia inducible factor (HIF), a heterodimer comprised of $\alpha$ - and $\beta$-subunits, is one of several transcription factors that regulate $E P O$ gene expression, ${ }^{23,24}$ though HIF- $2 \alpha$ has been shown to be the primary regulator of EPO transcription. ${ }^{25-28} \mathrm{HIF} \alpha$ (subunits HIF-1 $\alpha$ or HIF-2 $\alpha$ ) protein levels are controlled by enzymes (HIF-prolyl hydroxylases [HIF-PH]) that hydroxylate the $\alpha$-subunit of HIF, targeting it for ubiquitination by the Von Hippel-Lindau (VHL) protein and subsequent degradation by the proteosome. ${ }^{29-34}$ HIF-PH activity increases with increased levels of oxygen, iron, and 2-oxoglutarate, and thus HIF-PH can act as a "sensor" of oxygen tension, iron levels, and metabolic activity. As HIF protein levels increase due to decreased HIF-PH activity, the rate of Epo production in the kidney and liver as well as mobilization of iron to support increased erythropoiesis also increases. The renal Epo-producing cells appear to be either "on" or "off" (Figure 2), and thus increased Epo production is due to recruitment of increased numbers of producing cells and

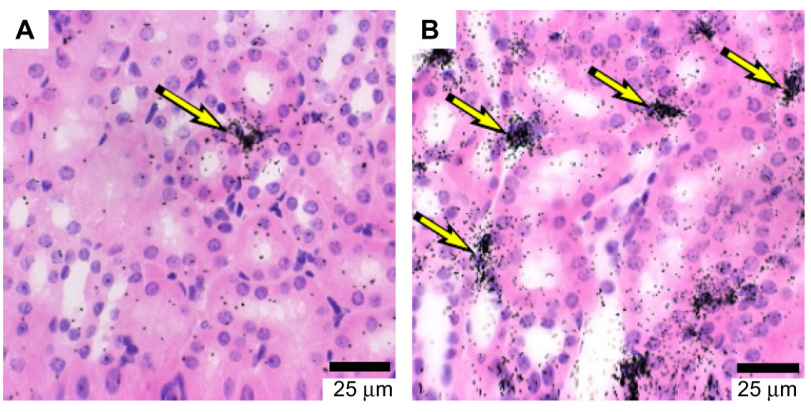

Figure 2 (A and B) Erythropoietin (Epo) mRNA is expressed in kidney interstitial cells. Mice were made anemic by withdrawing $0.5 \mathrm{~mL}$ blood and replacing with $0.5 \mathrm{~mL}$ saline 8 , 16, and 24 hours prior to sacrifice. Standard in situ hybridization (ISH) on kidney sections was performed with an antisense ${ }^{33} \mathrm{P}$-labeled Epo probe. (A) ISH for mouse Epo mRNA in a control mouse; (B) ISH for mouse Epo mRNA in an anemic mouse.

Notes: Increased number of cells expressing Epo transcripts in kidney from anemic mice vs normal mice, but with a similar number of grains over renal Epo-producing cells from both normal and anemic kidneys. Data and figure kindly provided by Sheilah Scully, Amgen.

not due to an increase in rate per cell. ${ }^{35,36}$ Under conditions of severe anemia and therefore low $\mathrm{O}_{2}$ concentration, Epo levels can increase up to 1000 -fold. ${ }^{37}$

The administration of Epo increases erythropoiesis, but has limited effects on other aspects of hematopoiesis. This conclusion is supported by a number of studies. Epo and EpoR knockout mice had an absence of post-CFU-E erythroid cells but numbers of earlier progenitor cell types - CFU-E, BFU-E, CFU-granulocyte macrophage, and CFU-megakaryocyte - in fetal liver were normal..$^{38}$ These observations indicated that Epo was not essential for the generation of these progenitor cells. Though administration of Epo to animals and humans resulted in a rapid stimulation of erythropoiesis, the total bone marrow (BM) cellularity and numbers of myeloid, lymphoid, and megakaryocytes remained unchanged..$^{17,39-43}$ Epo was also unable to stimulate early murine multipotential hematopoietic progenitor cells $\left(\mathrm{Lin}^{-}, \mathrm{Sca}^{+}\right){ }^{44}$ Finally, in humans, constitutive overexpression of Epo affected erythropoiesis but not other hematopoietic lineages ${ }^{45}$ and subjects with polycythemia due to a hypersensitive EpoR had normal white blood cell and platelet counts. ${ }^{46}$

Epo is expressed primarily in the kidney and liver, ${ }^{47,48}$ with minimal levels of transcripts detected in most other tissues, including brain, heart, and lung. ${ }^{36,49-57}$ In a normal adult animal, the kidney produces $70 \%-90 \%$ of the total Epo, with much of the remainder produced in the liver. ${ }^{57-60}$ The Epo-producing liver cell is a hepatocyte, ${ }^{36}$ while in the kidney, it is a neuronal fibroblast cell type found in the interstitial region near the proximal tubular cells (Figure 2). ${ }^{36,51,55,61,62}$ Consistent with the detection of Epo transcripts primarily in kidney and liver, transgenic mice expressing LacZ or green fluorescent protein (GFP) under control of an Epo promoter 
showed B-gal activity/GFP in liver and kidney but not other tissues, including brain and lung. ${ }^{36,63}$ Although there are some reports that Epo expression may extend to other tissues and cell types (including cells in the brain), these data were based on Western immunoblot and immunohistochemical (IHC) methodologies that used nonspecific or insensitive antibodies or reverse transcription-polymerase chain reaction (RT-PCR). ${ }^{64-71}$ Therefore, the results of antibody studies are inconclusive. Furthermore, the significance of mRNA detection by nonquantitative RT-PCR is unclear, because there was no evidence provided that the transcripts were translated into significant amounts of Epo protein.

\section{Erythropoietin receptors}

The EPOR ${ }^{72-74}$ is encoded by a single gene found on human chromosome $19 \mathrm{p}$ and mouse chromosome $9{ }^{72,75}$ It expresses a 2.0-2.2-kb mRNA that is translated into 508 aa (human) and 507 aa (mouse) proteins. ${ }^{20,74}$ After the removal of the 24 aa signal peptide, 484 aa (human) and 483 aa (mouse) proteins with a calculated molecular weight of approximately $53 \mathrm{kDa}$ are generated. ${ }^{76}$ Addition of an $N$-linked carbohydrate chain results in a protein with an estimated size of $56-57 \mathrm{kDa}$, which is comparable to the size of mature human and murine EpoR as determined by Western immunoblot analysis $(\sim 59-61 \mathrm{kDa}){ }^{76-78}$ The mature form is then transported to the cell surface, making it accessible for binding to Epo.
However, transport of EpoR to the cell surface is inefficient, and the majority of EpoR is detected in the endoplasmic reticulum, Golgi, and endosome-like structures. ${ }^{79}$ Less than $10 \%$ of the total EpoR protein synthesized appears on the cell surface ${ }^{80-83}$ The remainder is degraded, but EpoR "fragments" can be detected by Western blotting with specific anti-EpoR antibody A82. ${ }^{78}$

Cloning of the mouse and human EPOR genes $^{73,74}$ allowed for the further identification of potential EpoR-expressing and Epo-responding cells. According to in situ hybridization studies using EPOR probes, EPOR transcripts were detected in erythroid progenitor cells, with no EpoR transcripts detected in other hematopoietic cell types or in nonhematopoietic tissues, including adult liver, heart, skeletal muscle, and kidney. ${ }^{20,74,84-86}$ High-level EPOR mRNA expression was detected by Northern blot analysis in megakaryocyte/erythroid cell lines, but levels were low to undetectable in other types, including pluripotent embryonic stem/carcinoma cells, multipotent hematopoietic cells, myeloid progenitors, and committed lymphoid and macrophage precursors. ${ }^{87} \mathrm{With}$ the advent of more sensitive PCR and microarray methodologies, EPOR transcripts were detected in multiple nonerythroid cell types from the BM compartment as well as in various normal and tumorous tissues. ${ }^{56,64,84,85,88-94}$ However, compared to erythroid progenitor cells and tissues containing them, levels are relatively low, as shown in Figure 3.

EPOR

GATA-1

SCLITAL1

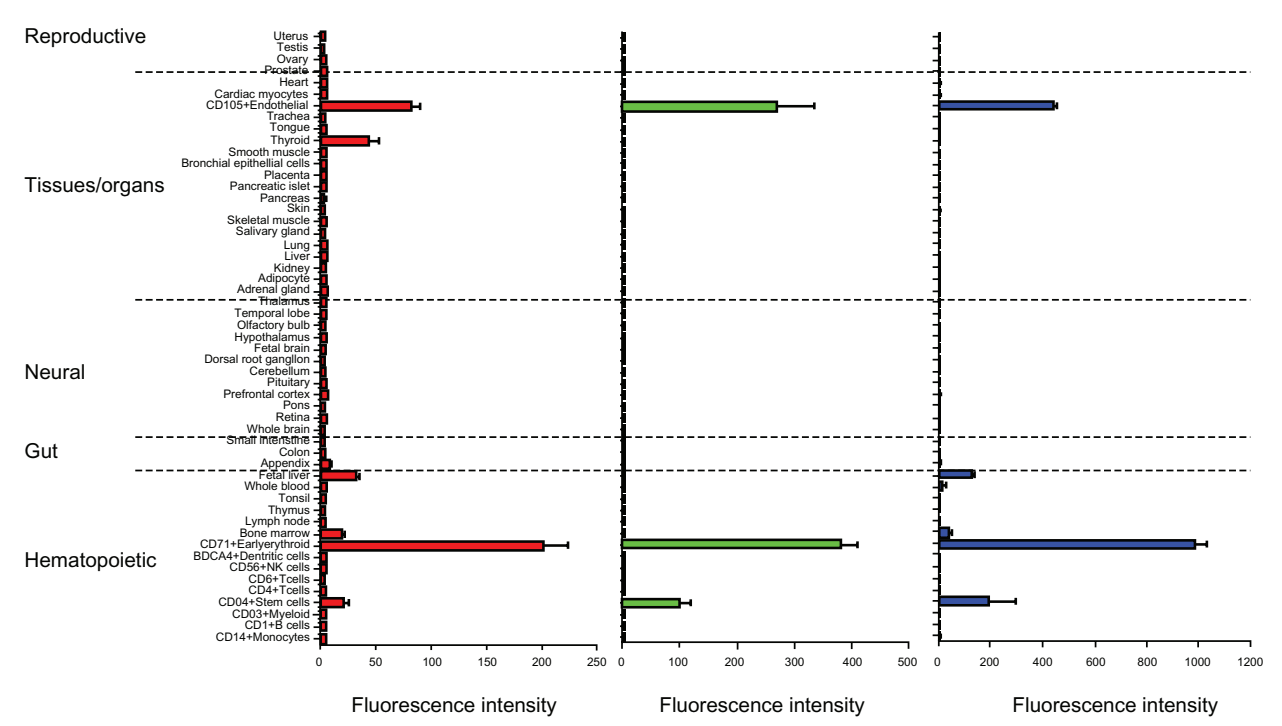

Figure 3 Erythropoietin receptor (EPOR), GATA-I, and SCLITALI have similar transcript profiles in normal human tissue.

Notes: Illustrated are levels of transcript (average of $\mathrm{n}=2$ ) and standard error obtained through microarray analysis of normal human tissue for EPOR, GATA-I, and SCL/ TALI. Levels of expression are in mean fluorescence units. Data were obtained from the publicly available database http://biogps.org. Probes shown are: EPOR, 209962_AT; GATA-I, 210446_AT; SCL, 206283-s_AT. Similar intensities were observed with other probes. Note that high-level expression of EPOR mRNA is found primarily in tissue/cell types containing erythroid cells. CDI05 (endoglin) is expressed in endothelial cells, but it is also coexpressed with CD7I in erythroid cells. ${ }^{343,344,461}$ Thus the EPOR detected in $\mathrm{CDIO5}^{+}$cells is likely due to erythroid cell-specific expression. 
The observation that EPOR transcripts could be detected at low levels outside the erythroid compartment suggested that EpoR protein could be generated and that therefore Epo could potentially have effects in nonerythroid tissues. Indeed, initial Western immunoblot and IHC experiments with anti-EpoR antibodies suggested that EpoR protein was widely expressed in nonerythroid cells at relatively high levels. ${ }^{95}$ However, these results were confounded, as nonspecific antibodies with poor sensitivity and specificity were used. ${ }^{76,91,96-98}$ Concerns regarding anti-EpoR antibody specificity and sensitivity first became apparent when the reported size of putative EpoR proteins detected by Western blot differed from the calculated molecular size of EpoR in positive controls. ${ }^{76}$ Furthermore, putative EpoR proteins were also detected in EpoR negative control cells with these anti-EpoR antibodies. ${ }^{76}$ The use of nonvalidated anti-EpoR antibodies has caused significant confusion and conflicting data in the literature. ${ }^{99,100}$ This issue is not unique to EpoR, as nonspecificity of antibodies has caused issues in the reliable detection of many proteins. ${ }^{101,102}$ This has resulted in misdirected research and unnecessary or inappropriate clinical decisions.

Another reason why the detection of EpoR protein has been problematic is that in nonerythroid cells, the levels of EpoR expression are generally very low, and therefore sensitive and specific detection methods are needed. For example, according to radiolabeled $\left[{ }^{125} \mathrm{I}\right] \mathrm{rHuEpo-binding}$ assays, which are very sensitive, in erythroid progenitors EpoR was found to be expressed at $<2 \times 10^{3}$ surface receptors/cell. ${ }^{103,104}$ This contrasts with other receptors such as EGFR, which is expressed in epithelial cells at $1 \times 10^{5}$ to $1 \times 10^{6}$ receptors/cell. ${ }^{105,106}$ Using live freshly derived cells, Epo binding was detected on the surface of erythroid progenitor cells, ${ }^{107,108}$ but not on unfractionated bone marrow, macrophage, thymocytes, monocyte, granulocyte, or late myeloid precursor cells; ${ }^{104,108-113}$ or on cells from normal tissues, including heart, kidney, brain, and lung. ${ }^{8}$ Recently, a sensitive and more-specific anti-EpoR monoclonal antibody (A82) suitable to detect low levels of EpoR by Western immunoblot was described. ${ }^{78}$ Results with A82 indicated that only erythroid cells had high levels of EpoR protein, with low to undetectable levels in other nonhematopoietic tissues and hematopoietic cell types (Figure 4). ${ }^{80,94}$

\section{Regulation of EpoR}

During normal erythroid differentiation, EpoR mRNA and surface protein increase as cells progress through the BFU-E to CFU-E stage, ${ }^{11,20}$ with a decline thereafter and an absence of detectable expression on reticulocytes and

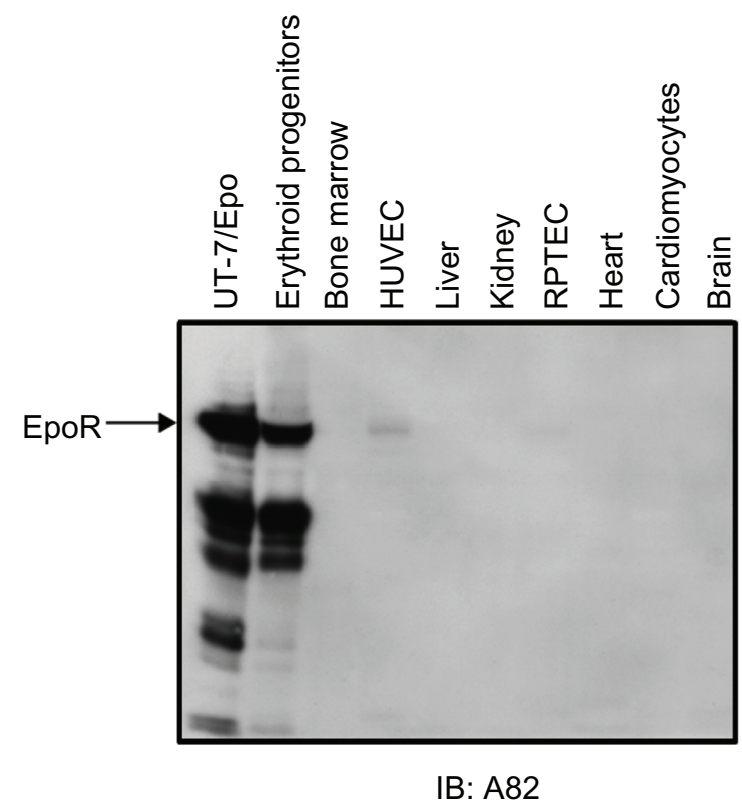

Figure 4 High-level erythropoietin receptor (EpoR) protein expression is found in erythroid cells but not in other tissues. EpoR expression was analyzed by Western immunoblot analysis with anti-EpoR antibody A82 that was shown to specifically detect human EpoR in erythroid cells. ${ }^{78}$ The arrow shows the location of full-length EpoR. Smaller proteins have been shown elsewhere to be EpoR fragments. ${ }^{78}$ UT-7/ Epo cells (EpoR positive control) are derived from a megakaryoblastic leukemia and are Epo-dependent. ${ }^{462}$

Notes: This research was originally published in Blood. Sinclair AM, Coxon A, McCafferyl, et al. Functional erythropoietin receptor is undetectable in endothelial, cardiac, neuronal, and renal cells. Blood. 2010;115(21):4264-4272. (C) American Society of Hematology. ${ }^{94}$

Abbreviations: HUVEC, human umbilical vein endothelial cells; RPTEC, renal proximal tubule epithelial cells.

$\mathrm{RBCs}^{104,110,111,114,115}$ (Figure 1, Figure 5). In knockout mice, neither Epo nor EpoR were required for the formation of BFU-E cells or the transition to the CFU-E stage. ${ }^{116}$ EpoR is required for the Epo-dependent expansion and survival of erythroid progenitors as they differentiate from CFU-E into mature hemoglobinized RBCs, and Epo responsiveness correlates with EpoR expression level. ${ }^{20,104,113,115,117}$ The observation that BFU-E grew with GM-CSF or interleukin (IL)-3 plus Epo but not with Epo alone, but did grow with Epo alone if EpoR expression was increased by forced overexpression using retrovirus-mediated gene transfer, ${ }^{108}$ suggests that increased $E P O R$ mRNA and protein expression is an important step preceding Epo responsiveness. However, increased EPOR mRNA is necessary but not sufficient for surface EpoR expression, ${ }^{118}$ and other factors are required, such as JAK2, which acts as a key signaling intermediate as well as a chaperone. ${ }^{119}$

EPOR mRNA has a relatively long half-life, approximately 90 minutes in human cells and 75 minutes in murine cells, ${ }^{20,120}$ and the half-life is not affected by Epo or by cellular differentiation. The EPOR promoter was found to be 


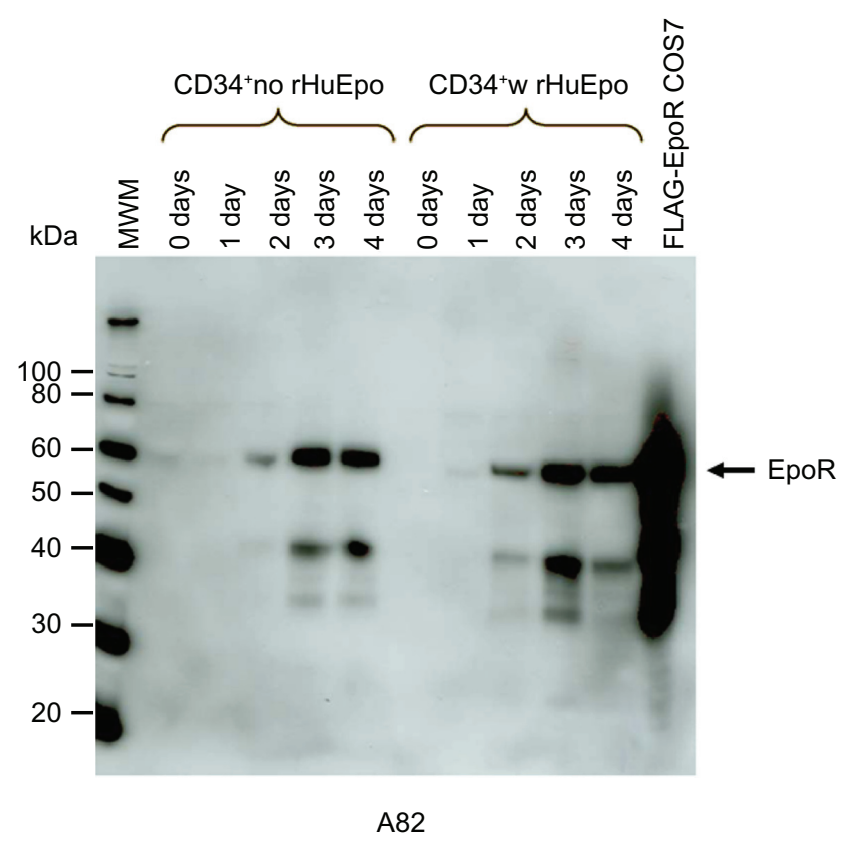

Figure 5 Erythropoietin receptor (EpoR) expression in differentiating CD34+ hematopoietic progenitor cells grown with or without Epo.

Notes: CD34+ cells were cultured in medium containing $50 \mathrm{ng} / \mathrm{mL}$ stem cell factor, $10 \mathrm{ng} / \mathrm{mL}$ interleukin (IL)-3, $10 \mathrm{ng} / \mathrm{mL}$ IL-6 with (w/) and without (no) $5 \mathrm{U} / \mathrm{mL}$ recombinant human erythropoietin (rHuEpo) for the indicated number of days. The arrow denotes the position of full-length EpoR ( $59 \mathrm{kDa})$. FLAG-EpoR COS7 is an EpoR positive control cell lysate from COS-7 cells expressing a FLAG-tagged version of EpoR. ${ }^{76}$ Data and figure kindly provided by Leigh Busse, Amgen. Abbreviation: MWM, molecular weight marker in kilo Daltons $(\mathrm{kDa})$.

active in erythroleukemia cell lines MEL and HEL, but not in nonerythroid cell types, including NIH3T3, HeLa, EL4, S194, WEHI-3, or COS. ${ }^{121-125}$ These findings suggested that EPOR gene transcription is controlled by essential erythroidspecific transcription factors that are limiting or absent in some cell types. In one study, the sequence of the EPOR in Epo-responsive and -unresponsive mouse erythroleukemia cells was the same, ${ }^{126}$ suggesting that lack of response was not due to defects in EpoR itself.

Reporter experiments have been performed in transgenic mice to track the in vivo expression of endogenous EpoR in different cell populations. Using the Cre-Lox system, EpoR Cre mice were crossed to Lox Rosa26 enhanced yellow fluorescent protein (eYFP) reporter mice, and expression of eYFP was found to correlate with activity of the EpoR promoter. ${ }^{127}$ In hematopoietic cells, eYFP was detected in erythroid cells up to the erythroblast stage. However, no eYFP was detected in megakaryocytes, platelets, macrophages, granulocytes, monocytes, or leukocytes. Further, eYFP was not detected in highly purified hematopoietic stem cells, mesenchymal, or osteoblastic enriched populations from the bone microenvironment. In a similar experiment, GFP-Cre was introduced into the EPOR locus by homologous recombination. ${ }^{88}$ With this construct, EpoR-driven Cre activity was observed in Ter119+ erythroid cells but not in other hematopoietic lineages, including granulocytes, macrophages, monocytes, leukocytes, lymphoid cells, megakaryocytes, or platelets, nor in early Sca- $1^{+}$hematopoietic "stem cells." Cre activity was observed in fetal liver and bone marrow, but not in any other tissue, including brain, heart, lung, and kidney. These observations are consistent with in situ EpoR hybridization experiments with tissues and purified hematopoietic cell types (see above) where high-level EpoR mRNA expression was detected only in erythroid cells or tissues containing erythroid cells.

EpoR expression does not appear to be controlled by Epo. In support of this, EpoR protein is increased in the absence of Epo in differentiating erythroid cells (Figure 4), and in nonhematopoietic tissues, EpoR mRNA levels were not altered in Epo-deficient skeletal muscles, ${ }^{128}$ nor were EpoR levels changed when endothelial cells were cultured with Epo. ${ }^{129}$

EpoR also does not appear to be regulated by hypoxia. Neither EPOR transcripts ${ }^{22,80,91,130-135}$ nor protein levels ${ }^{80}$ were increased under hypoxic conditions. The lack of elevated EPOR transcription with hypoxia is consistent with the absence of a consensus hypoxia response element in the EPOR transcriptional regulatory regions. However, some reports have suggested EpoR expression is regulated by hypoxia. ${ }^{132,134,136-140}$ These latter data are confounded, because the studies were not appropriately controlled and conclusions were based on the use of nonspecific anti-EpoR antibodies to detect EpoR by IHC.

Several different transcription factors have been reported to play a role in regulating EPOR transcription, including GATA-1. ${ }^{43,123}$ GATA-1 knockout mice do not develop erythroid cells, but are able to develop other hematopoietic cell types. ${ }^{141-143}$ GATA-1 expression is primarily restricted to the erythroid lineage and is essential for high-level EPOR promoter activity. ${ }^{123}$ Indeed, this relationship can be seen when EPOR and GATA-1 mRNA levels in various tissues are compared (Figure 3). EPOR transcript levels correlate with GATA-1 transcript levels across tissue and cell types, levels of both change concomitantly during cell division, ${ }^{144}$ both are expressed in the same cell types during erythropoiesis, ${ }^{145}$ and GATA-1 levels correlate with Epo responsiveness in cell lines. ${ }^{146,147}$ However, GATA-1 alone is insufficient to drive EPOR expression, and other factors appear to be essential, including Friend of GATA (Fog1), ${ }^{148}$ a factor that forms a complex with GATA-1; ${ }^{149}$ the erythroid specific factor $S C L /$ TAL1, ${ }^{150-153}$ which demonstrates a similar expression profile 
as EPOR and GATA-1 (Figure 3); and ETV6/RUNX1, which when overexpressed can also increase EPOR gene transcription. ${ }^{154}$ Consistent with a similar tissue expression profile, SCL/TAL1 is coexpressed with GATA-1 in the same hematopoietic cells. ${ }^{155}$ Another possible regulator is SP1, a transcription factor found in lysates from erythroid but not in nonerythroid cell lysates. ${ }^{124}$

The EPOR promoter appears to be leaky because transcript levels are detected in numerous cell types, albeit at lower levels compared to erythroid cells. This is consistent with the finding that the EPOR gene promoter has characteristics of a ubiquitously expressed gene (ie, lacks a TATA box) and thus should have low basal transcription in nonerythroid cells. ${ }^{156,157}$

\section{Activation of EpoR}

Activation of EpoR is initiated by the direct binding of a single Epo molecule with two membrane-spanning EpoR proteins $^{158-160}$ that form a homodimer (Figure 6). The binding of Epo induces a conformational change in EpoR that brings the transmembrane and intracellular regions of the receptor in close proximity. Following binding, the Epo-EpoR complex is activated, internalized, and some is degraded in lysosomes, with the remainder recycled to the cell surface. ${ }^{8,161}$ However, EpoR can also be internalized and degraded in lysosomes without Epo binding and activation. ${ }^{162}$

EpoR does not contain intrinsic tyrosine kinase activity but instead requires an accessory tyrosine kinase (JAK2) to induce the signaling cascade. ${ }^{119}$ JAK2 interacts with EpoR at the juxtamembrane region, ${ }^{119}$ and the conformational change induced by Epo binding to EpoR ${ }^{163,164}$ brings the JAK2 molecules into close proximity, resulting in their transphosphorylation. ${ }^{165}$ The activation of JAK2 results in the phosphorylation of tyrosine residues in EpoR, which serve as docking sites for mediators of the STAT5, MAP kinase, and PI3 kinase/Akt signaling pathways ${ }^{166}$ (Figure 6). Following activation, negative regulators of EpoR, including Src homology region 2 domain-containing phosphatase 1 and suppressor of cytokine signaling proteins SOCS-1 and SOCS-2, down-modulate signaling responses. ${ }^{167,168}$ Further control of Epo-induced signaling in cells is mediated through

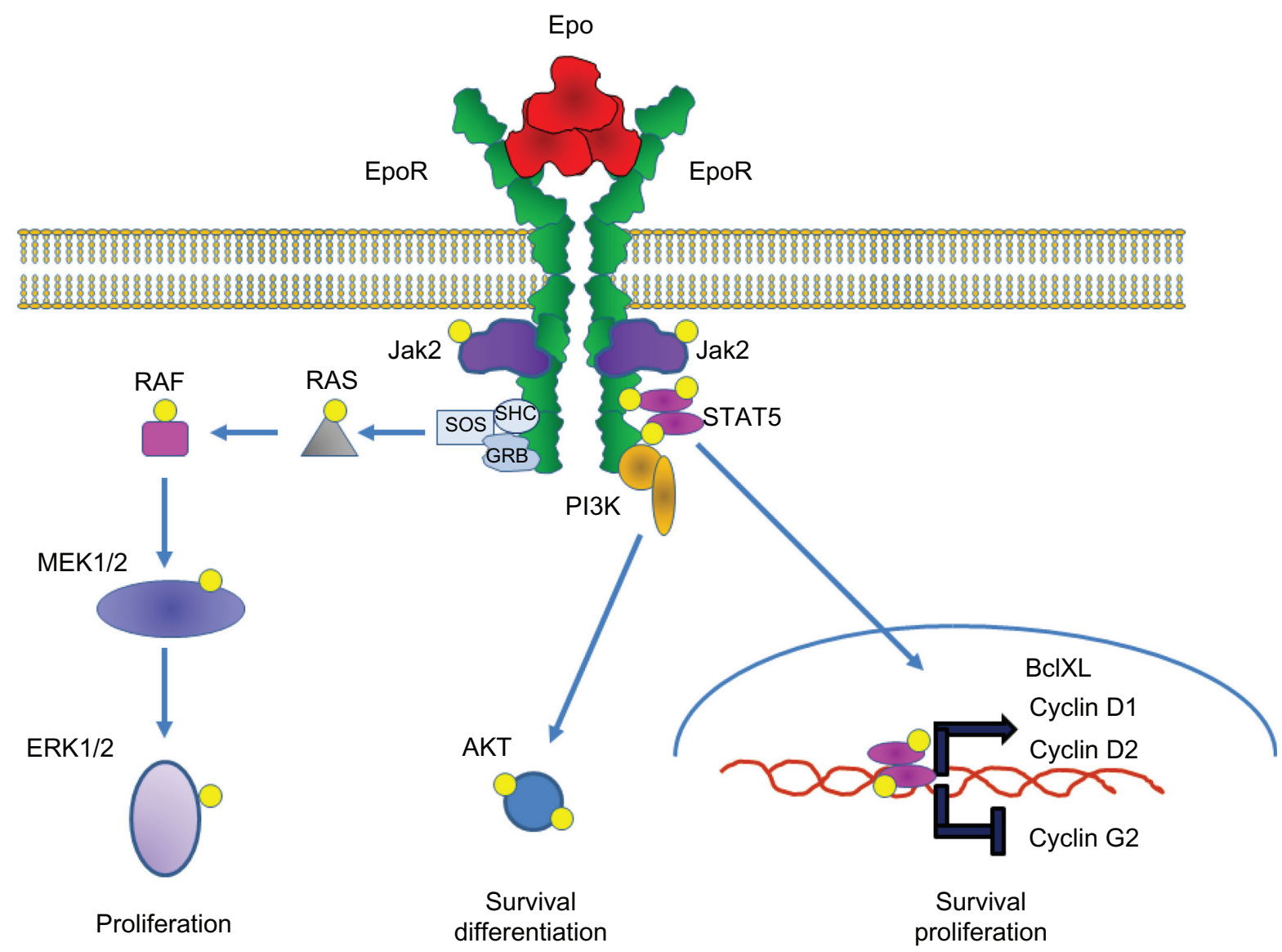

Figure 6 Erythropoietin receptor (EpoR) activation and signaling with Epo in erythroid progenitor cells.

Note: Schematic diagram of the signaling cascades and effector responses observed in erythroid progenitor cells when EpoR is activated with erythropoiesis-stimulating agents. 
inhibition of EpoR cell surface expression through ubiquitination and subsequent proteosomal degradation. ${ }^{169}$

The rate of assembly of a functional EpoR homodimer is EpoR concentration-dependent. ${ }^{158,170}$ In HEL cells, the magnitude of increase in phosphorylated JAK2 after Epo treatment, minimal in the parental cells, is increased with overexpression of EpoR. ${ }^{171}$ However, levels of surface EpoR are not always correlated with EPOR mRNA level. ${ }^{172}$ Thus, low-level protein production and/or inefficient EpoR processing and surface translocation may be limiting factors for Epo-EpoR responses. In support of this possibility, increasing levels of EpoR in growth factor-dependent cell lines caused them to become demonstrably Epo-responsive..$^{20,104,108,147,171,173,174}$ EpoR levels also appear to affect magnitude of response to Epo in vivo. For example, mice that were haplo-insufficient (EpoR ${ }^{+/-}$mice) had reduced hematocrit and reduced responsiveness of CFU-E to Epo compared to normal mice. ${ }^{175}$ While these studies indicate that a minimal level of EpoR expression is required for a functional response, the absolute level of EpoR required is unclear. SH-SY5Y cells (a neuroblastoma cell line) were reported to respond to rHuEpo despite very low levels of surface EpoR, less than 50 surface EpoR/cell. ${ }^{176,177}$ However, others could not detect responses in SH-SY5Y cells. ${ }^{91,94,178}$

Another possible explanation for the lack of functional EpoR in some cells even though the receptor protein is expressed is that other accessory factors for functional responses are missing. Consistent with this proposal, the leukemia cell lines K562 and OCIM-1 do not respond to Epo (signaling or proliferation/survival) despite detectable EpoR expression on the cell surface using Epo-binding assays. ${ }^{103,112,115}$ In addition, EpoR was detected at $~ 1000$ receptors/cell in other cell lines derived from patients with acute myelogenous leukemia (AML), chronic myelogenous leukemia (CML), and erythroleukemias, but only some were responsive to Epo. ${ }^{73,103,179-182}$ This may be at least partly explained by constitutive activation of pathways making them nonresponsive to cytokine stimulation. ${ }^{183}$ For example, K562 cells have the Bcr/Abl fusion, ${ }^{184}$ while OCIM-1 cells have constitutive phosphorylation of STAT5, though the pathways contributing to this constitute activation are unknown. ${ }^{185}$ However, other processes could also be defective in those cells, explaining the lack of Epo-EpoR response.

EpoR overexpression can confer Epo dependence in some cell types but not others, indicating EpoR expression is necessary but not sufficient for a response. For example, forced overexpression of EpoR resulted in Epo dependence for growth in factor-dependent murine progenitor cell lines (FDCP-1, 32D, BaF3) but not in others, such as mouse IL-2-dependent T-cell lines HT-2 and CTLL2 ${ }^{186-195}$ or in $\mathrm{NIH}-3 \mathrm{~T} 3$ cells, ${ }^{121}$ which are dependent on platelet-derived or fibroblast growth factor for growth. ${ }^{196}$ Infection of BM cells with virus expressing EpoR or a constitutive-active EpoR variant (R129C) resulted in an increase in erythroid, macrophage, and megakaryocyte cells but not other lineages, including lymphocytes, granulocytes, mast cells, and eosinophils. ${ }^{108,197-199}$ This suggests that macrophage and megakaryocyte progenitors cells are programmed for a response but lack sufficient EpoR expression, while other cell types lack programming. For example, HT-2 cells expressing EpoR failed to grow with Epo despite Epo-induced phosphorylation of EpoR and JAK2. However, these cells had a deficit in Epo-induced STAT5 phosphorylation, ${ }^{186}$ suggesting a deficiency in downstream signaling pathways. A somatic fusion of EpoR-expressing HT-2 cells with $\mathrm{BaF} 3$ cells resulted in Epo dependent growth and signaling, suggesting addition of an essential factor by BaF3 cells. Taken together, these observations suggest that in addition to the accumulation of a certain level of EpoR, the cells must contain the required intracellular signaling networks for a "programmed" response.

\section{Is functional EpoR expressed in tumor cells?}

The potential for ESAs to stimulate tumor growth has been of significant controversy since 2003, when it was reported that patients with head and neck cancer receiving rHuEpo had reduced locoregional control of their tumors compared to control subjects. ${ }^{2,200}$ This was followed by an analysis of patient samples for expression of EpoR, ${ }^{201}$ in which an association between staining with the anti-EpoR antibody C-20 and negative clinical outcomes was reported. This raised the hypothesis that EpoR was expressed on tumors and that ESAs directly stimulated tumor growth. This hypothesis appeared to be supported by preclinical data that suggested that most tumors and cell lines expressed high levels of EpoR, and further that ESAs directly promoted tumor cell growth and survival. ${ }^{100,202,203}$ However, these data contrasted with data from other groups that reported EpoR was not present on tumor cells and that ESAs did not have a direct tumorstimulating effect. ${ }^{99,204-206}$ Further, with clinical data from other trials and meta-analyses, there was not a significant association between ESAs and tumor progression end points. ${ }^{2}$ These conflicting data have caused considerable confusion and have led to calls for additional research. Here, we provide 
a critical evaluation of the research that pertains to the expression and function of EpoR in tumor cells.

Tumor growth is commonly driven by oncogenes, which are marked by shared characteristics, including overexpression due to genomic amplification, mutations that induce constitutive activation, and increased transcriptional/translational activity. Although EPOR genomic amplification and gene rearrangements have been described in some erythroleukemia and megakaryoblastic leukemias and derived cell lines (eg, UT-7 F36E and TF-1), ${ }^{172,207-209}$ EPOR amplification is thought to be a rare event. Several studies failed to show amplification of EPOR or alterations to chromosome 19, the location of the EPOR gene, ${ }^{209,210}$ even in erythroleukemia, the disease above all others in which involvement of Epo/EpoR might have been predicted. Furthermore, in contrast to oncogenic receptors such as HER2 and EGFR, in a screen of $>1000$ different solid tumors, EpoR gene amplification was rarely found, and when observed was similar to the frequency and magnitude of amplification of other nononcogenes. ${ }^{92}$

Constitutive activation of EpoR could theoretically also provide a growth advantage to tumors. This has been observed with Friend virus infection, which results in constitutive activation of EpoR through the binding of Env protein gp55 to EpoR, and has been shown to induce erythroleukemia in mice. ${ }^{211,212}$ An activating mutation in murine EpoR was identified (R129C) in a mutagenesis screening study that induced constitutive activation and conferred growth factor independence in IL-3-dependent BaF3 cells. ${ }^{213}$ However, activating EpoR mutations do not appear to play a role in tumorigenesis, and naturally occurring activating EpoR mutations have not been found in human erythroleukemias. ${ }^{209,210}$ For example, EpoR sequence analysis was performed on six tumor cell lines (UT-7/Epo, MCF-7, 769-P, CAKI-2, SH-SY5Y, and HeLa), and no activating EpoR mutations were found (Amgen data on file). Moreover, while EpoR hyperactivating mutations ${ }^{214,215}$ have been reported in patients with congenital erythrocytosis, these subjects had normal platelet and white blood cell counts and no increased incidence of tumors or leukemic transformation, ${ }^{192,209,211,216-218}$ and were otherwise normal.

A prerequisite for a direct effect of ESAs on tumor cells is that they must express EpoR. EPOR mRNA was detected in multiple tumor cells and cell lines using RTPCR. ${ }^{20,90,96,134,219-228}$ However, EPOR transcript levels were 10-1000-fold lower in tumor tissues and cell lines compared to Epo-responsive positive control cells. ${ }^{64,80,91,229-234}$ These results were consistent with Northern analysis of solid tumor and leukemic cell lines, in which EPOR mRNA was expressed at low to undetectable levels. ${ }^{87,235}$ One group reported a direct correlation between EPOR transcript levels and poor clinical outcome in a subset of patients treated with ESAs, but definitive prognostic conclusions could not be made. ${ }^{230}$ Moreover, levels of EPOR mRNA in tumors were similar to that of their normal counterpart. ${ }^{92,134}$ These data demonstrate that though the EPOR gene is expressed in normal tissues and tumor cells, EPOR mRNA transcripts are not overexpressed in tumors, with levels detected representing the low basal transcription seen in normal tissues.

As EPOR mRNA was detected in tumors, it seemed likely that EpoR protein was also present on tumor cells. Indeed, Henke et al reported that high levels of EpoR protein was expressed in tumors from head and neck cancer patients who had poor outcomes when treated with ESAs using IHC studies. ${ }^{201}$ EpoR expression was also reported by multiple groups in various tumors and tumor cell lines by Western immunoblot and IHC using the same antibody (C-20). ${ }^{236-242}$ Over 30 different studies have been published with putative detection of EpoR in tumors and tumor cell lines that all used the C-20, M-20 and H194 antibodies (produced by the same manufacturer - Santa Cruz Biotechnology). These studies were thought to indicate that ESAs may stimulate EpoR expressed in tumors and thereby promote tumor growth and survival. However, analysis of the Henke et al clinical samples indicated that the level of EpoR protein expression suggested by the C-20 staining did not correlate with the level of EPOR mRNA. ${ }^{230}$ In addition, not all groups reported correlations between C-20 antibody staining of other clinical tumor specimens and adverse clinical events. ${ }^{243-246}$ Further, in cells deemed to be EpoR-positive through staining with C-20 antibody, no cellular responses, such as changes in proliferation or viability, were observed. ${ }^{247}$ These discordant results were highlighted in a study in which tumor cells from patients with B-CLL were reported to express EpoR using a nonspecific anti-EpoR antibody, but no EpoR protein was detected on the cell surface using a more specific digoxigenin-labeled rHuEpo binding method. ${ }^{96}$

Several issues have recently come to light in the analysis of anti-EpoR antibodies, including C-20: the putative EpoR proteins detected with the antibodies varied in size by Western immunoblot analysis, were detected in negative control cell lines, differed in size from the EpoR detected in positive control samples, and in control studies many were shown to be nonspecific. . $^{9,91,97,98,230,248,249}$ Therefore, it is likely that the putative EpoR detected with these antibodies were non-EpoR cross-reacting proteins, thereby giving false-positive results. One of the proteins detected by $\mathrm{C}-20$ was $66 \mathrm{KDa}$ in size 
and thought to be EpoR, but was subsequently shown to be heat shock protein (HSP)70. ${ }^{76}$ Since HSP70 is ubiquitously expressed and expression is increased when cells and tumors undergo stress responses, the IHC results reported with C-20 may have reflected HSP70 biology and not EpoR. The use of nonspecific antibodies in general, ${ }^{101}$ and anti-EpoR antibodies in particular, ${ }^{76}$ is a well-recognized problem in research that has resulted in recommended guidelines for antibody validation. ${ }^{250-254}$

Recently, a specific and sensitive anti-EpoR antibody (A82) suitable for detecting EpoR by Western immunoblot analysis was described. ${ }^{78}$ Using A82 in Western analyses of total protein lysates (intracellular and cell surface protein), EpoR was undetectable in normal nonhematopoietic human and mouse tissues ${ }^{94,185}$ and in tumor specimens from breast, lung, ovary, colon, and skin. ${ }^{255}$ In another analysis of 66 tumor cell lines with A82, 80\% of the lines had over 100-fold lower or undetectable levels of EpoR compared to a positive control hematopoietic cell line. ${ }^{80}$ The remaining cell lines had relatively low levels (5-100-fold lower) compared to that observed with a positive-control hematopoietic cell line. Only one tumor cell line (the NSCLC line NCI-H661), which had the highest level of total EpoR, had detectable EpoR on the cell surface according to $\left[{ }^{125} \mathrm{I}\right] \mathrm{rHuEpo-binding}$ experiments. However, neither NCI-H661 nor any of the other solid tumor lines examined responded to ESAs in signaling studies. ${ }^{80}$ Mouse monoclonal antibody MAB307 has also been used to detect cell surface EpoR by flow cytometry. While EpoR was detected on positive controls, including primary erythroid progenitors with MAB307, no EpoR was detected on the surface of viable tumor cells from over 180 different biopsies from patients with tumors including breast, colon, ovary, lung, head and neck, and kidney. ${ }^{256}$ These findings are consistent with Western immunoblot data generated with A82.

Another method used to examine surface EpoR in tumor cells and cell lines is competitive binding experiments with labeled rHuEpo. Specific rHuEpo binding to some hematopoietic cells and certain myeloid and erythroleukemia cells and cell lines was reported. ${ }^{103,107,112,257}$ However, surface EpoR was not detected in primary hematopoietic leukemias, such as B-CLL or multiple myeloma, ${ }^{258}$ or in most hematopoietic cell lines and nonhematopoietic cancer cell lines. ${ }^{78,80,92,103,113,115,180,259,260}$ In a controlled flow cytometry study using biotinylated rHuEpo, 81/136 samples from AML patients were reported to bind rHuEpo, of which only 13 of 81 had an increase in growth with rHuEpo treatment. ${ }^{257}$ However, there was no correlation between the amount of
EpoR and the in vitro proliferative response to $\mathrm{rHuEpo.}$ In the same study, 4/14 acute lymphoblastic leukemia patient samples were reported to bind rHuEpo, but none proliferated with rHuEpo. In other studies, one group reported that rHuEpo increased colony number and plating efficiency with cells from CML patients. ${ }^{261}$ In contrast, in other studies, no proliferative effect of ESAs in AML and B-cell leukemic cell types were found, ${ }^{258,262}$ and $\mathrm{rHuEpo}$ did not have an effect on STAT5 phosphorylation on those cells. ${ }^{263}$

A few studies have evaluated $\left[{ }^{125} \mathrm{I}\right] \mathrm{rHuEpo}$ binding in epithelial tumor cell lines. While some studies have reported specific binding to solid tumor cell lines, ${ }^{235,264,265}$ other studies reported none. ${ }^{80,99}$ In Epo-responsive hematopoietic cell lines and primary erythroid cells, rHuEpo has a high binding affinity $(\mathrm{Kd} \sim 50-400 \mathrm{pM}) .{ }^{103,104,109,172,266,267}$ In contrast, in the studies with solid tumor cells that reported binding, the rHuEpo binding affinity was unusually low (Kd 1400-16,000 pM). The low affinities reported in these studies may be due to nonspecific interactions of $\mathrm{rHuEpo}^{268}$ related to the hydrophobic nature of rHuEpo.

To independently determine if functional EpoR was present on the cell surface, investigators have also examined EpoR downstream signaling events after treatment of cells with ESAs in vitro. Signaling through EpoR is dependent on JAK2, which transduces downstream signaling though the STAT5, PI3K, and MAPK pathways ${ }^{269}$ (Figure 5). Thus, positive results showing phosphorylation of JAK2 or STAT5 with ESAs in tumor cells would be important evidence for activation of EpoR with Epo. However, there are a number of reports indicating no increased phosphorylation of JAK2 or STAT5 with rHuEpo in tumor cell lines, ${ }^{80,193,270-272}$ with only rare positive reports: SH-SY5Y (neuroblastoma), H838 (lung cancer), and several head and neck cell lines. ${ }^{132,224,273,274}$ However the results in the SH-SY5Y and H838 cell lines were not reproducible by others. ${ }^{91,94,255}$

In other attempts to demonstrate specificity of potential responses to EpoR, a putative JAK2 inhibitor (AG490) has been used and effects on rHuEpo signaling and other functional effects in cell lines reported. ${ }^{132,246,275-278}$ However, AG490 shows minimal JAK2 inhibitory activity in vitro. ${ }^{279}$ Further, AG490 has been reported to also inhibit JAK3, EGFR, HER2, guanylyl cyclase C, and BCR-ABL. ${ }^{279-283}$ These data raise significant questions as to the validity of results from studies that have used AG490 to ascribe effects mediated through EpoR and JAK2.

In the studies reporting positive signaling effects of ESAs on tumors or tumor cell lines, increases in phosphorylation of ERK or AKT were reported. ${ }^{205,229,272,275,276,28}$ 
${ }^{4}$ However, those results are in conflict with results from other groups who reported no effect on the same pathways using the same or similar cell types. ${ }^{80,91,223,232,233,259,285}$ Interestingly, there are several reports where $\mathrm{rHuEpo}$ had no effects on phosphorylation of JAK2 or STAT5, but did have effects on ERK phosphorylation. ${ }^{271,272,276,284,286-288}$ In those experiments, cells were serum-starved to increase the signal-to-noise ratio, making them sensitive to minor manipulation/stimulatory effects. Because the MAPK, PI3K/AKT, and JAK2-STAT5 pathways are stimulated by multiple receptor ligand complexes beyond Epo, ${ }^{289-291}$ contaminating factors could produce similar effects. Indeed, signaling that had been suggested to be mediated through EpoR was mimicked in cell lines using a media change alone. ${ }^{292} \mathrm{ESA}$-induced signaling can also be mimicked with endotoxin, which can accumulate in contaminated preparations and can enhance AKT and ERK phosphorylation. ${ }^{293,294}$ Bovine serum albumin (frequently used to stabilize ESA preparations), can also support cell growth as well as stimulate ERK phosphorylation of cell lines, particularly when serum-starved cells are used, ${ }^{292,295}$ due to contaminants such as IGF $1^{296}$ and insulin. ${ }^{297}$

ESAs have also been evaluated for potential chemotaxis activity. In some studies, ESAs were reported to increase movement of cells in Matrigel in vitro. ${ }^{271,276,278,288}$ These data supported the hypothesis that ESAs could promote metastases of tumor cells. However, others reported no effect of ESAs on migration with the same or similar cell types. ${ }^{232,233,298-300}$ In some of the cell lines reported to migrate in Matrigel with ESAs (eg, MCF-7, HeLa), EpoR protein was undetectable, ${ }^{78,80}$ raising questions about the significance of data generated with those cell lines. Furthermore, the effects reported to be mediated by ESAs were generally small compared to molecules known to induce migration, such as EGF or FGF, ${ }^{298,300}$ and could be a result of endotoxin, a contaminant that can similarly stimulate migration. ${ }^{301-304}$

Effects of ESAs on tumor cell line proliferation have also been evaluated. However, in most studies, ESAs had no effect. ${ }^{99,205}$ For example, in a controlled study, though estradiol increased the proliferation of 29 tumor cell lines derived from multiple tissue sources, rHuEpo treatment did not. ${ }^{305}$ These findings were supported by studies in other groups that evaluated multiple different cell lines. ${ }^{80,91,300}$ However, in one study, rHuEpo was reported to enhance proliferation in a head and neck cell line LU-HNSCC-7 in serum-free medium $(<1.4$-fold increase). Notably, the authors commented that the effects observed could have been due to the medium change, although no control for that was presented. ${ }^{233}$
In primary tumors from renal and colorectal tumors, rHuEpo was also unable to stimulate proliferation. ${ }^{306}$ More recently, in a study with biopsies from a large cohort of patient samples with epithelial tumors $(>180)$ from breast, colorectal, lung, ovary, head and neck, and kidney, rHuEpo was unable to increase the phosphorylation of AKT, ERK, or STAT5 ex vivo. ${ }^{256}$ The lack of response may be explained by the lack of EpoR expression on those cells ${ }^{256}$ or the high incidence of constitutive activation of pathways rendering them insensitive to growth factor stimulation. ${ }^{263}$

In vivo xenograft studies have been used to examine the effect of exogenously administered ESAs on cell growth or the ability to prevent cell ablation with chemotherapeutic agents or radiotherapy in rodents. In 31 different studies, there was no tumor growth or survival-promoting effects observed, even when high doses of ESAs were used ${ }^{99,205}$ (Table 1). This may be explained, in part, because most of the cell lines examined expressed little to no EpoR, and therefore would not be expected to directly respond to ESAs. However, the lack of a tumor-promoting effect was not solely explained by insufficient EpoR, because even with cells (eg, in ovarian carcinoma line A2780) having tenfold-higher levels of EpoR due to forced overexpression, no growth-promoting effects with rHuEpo were observed. ${ }^{232}$ Further, one group performed studies using mice that produced spontaneous tumors, but again no increase in tumor incidence or growth with rHuEpo treatment was observed. ${ }^{307}$

In contrast to xenograft studies with ESAs, in vivo Epo antagonism studies have been described where the blockade of Epo-EpoR inhibited tumor growth. ${ }^{64,227,272,308}$ However, these reports are inconsistent with in vitro experiments demonstrating that the cell lines used expressed little/no EpoR and had no detectable response when treated with ESAs. Antagonism studies can be impacted by other inhibitors and factors, such as endotoxin in the preparations, that can inhibit tumor cells. ${ }^{309}$ The possibility that the tumor growth inhibition reported was due to the experimental design also cannot be excluded, as negative controls were not included in those studies. Taken together, these data suggest that functional EpoR is not expressed on tumor cells.

\section{Epo-EpoR autocrine/paracrine loops}

Paracrine stimulation of EpoR in cells has been reported to support growth of Epo-responsive cell lines. ${ }^{310,311}$ Accordingly, some groups have also suggested that both Epo and EpoR are coexpressed in tumor cells and this may be a mechanism that drives autocrine tumor growth. ${ }^{312-314}$ 
Table I Effect of erythropoiesis-stimulating agents in xenograft or syngenic tumor models

\begin{tabular}{|c|c|c|c|}
\hline Tumor type and origin & EPO/DA dose & Reported tumor and survival outcomes & Study \\
\hline \multicolumn{4}{|l|}{ Tumor regression alone } \\
\hline Murine myelomas MOPC-315, 5T33 MM & 30 U Epo QD & Tumor regression and prolonged survival & Mittelman et al ${ }^{440}$ \\
\hline Murine BCL-I leukemia/lymphoma & 30 U Epo QD & Tumor regression and prolonged survival & Mittelman 441 \\
\hline \multicolumn{4}{|l|}{ Enhanced tumor ablation } \\
\hline Neurogenic sarcoma ENE2 & 750 U/kg Epo TIW & Improved RT therapy in anemic mice & Stuben et $\mathrm{al}^{442}$ \\
\hline Lewis lung carcinoma & 60 U/kg Epo (two doses) & No effect alone; enhanced CT & Sigounas et $\mathrm{al}^{443}$ \\
\hline Rat DS-sarcoma & 1000 U/kg Epo & No effect alone; improved ablative RT & Thews et a $\left.\right|^{444}$ \\
\hline Ovary adenocarcinoma & 20 U Epo TIW & No effect alone; improved CT & Silver and Piver ${ }^{445}$ \\
\hline Glioblastoma HTZ II & I 000 U/kg Epo TIW & No effect alone; improved RT in anemic mice & Stuben et al ${ }^{446}$ \\
\hline Rat DS-sarcoma & 1000 U/kg Epo TIW & No effect alone; improved CT in anemic rats & Thews et $\mathrm{al}^{447}$ \\
\hline Colon adenocarcinoma & I 000 U/kg Epo QD & Restored PT in anemic mice & Golab et $\mathrm{al}^{448}$ \\
\hline Human glioblastomas GBM-NanI and U87 & 300 U/kg Epo QD & No effect on tumor alone; enhanced RT in both lines & Pinel et al ${ }^{357}$ \\
\hline $\begin{array}{l}\text { Murine SCC VII squamous cell carcinoma } \\
\text { and RIF-I fibrosarcoma }\end{array}$ & $30 \mu \mathrm{g} / \mathrm{kg}$ DA QW or Q2W & $\begin{array}{l}\text { No effect alone; improved RT in anemic } \\
\text { mice in both lines }\end{array}$ & Ning et $\mathrm{al}^{231}$ \\
\hline Lewis lung carcinoma & $10 \mu g / k g$ DA QW & No effect alone; improved CT & Shannon et $\mathrm{al}^{270}$ \\
\hline $\begin{array}{l}\text { Human squamous cell A43I, colorectal } \\
\text { carcinoma HT25 }\end{array}$ & I 50 U/kg Epo TIW & $\begin{array}{l}\text { No effect alone; enhanced CT } \\
\text { in both models }\end{array}$ & Tovari et al $\left.\right|^{449}$ \\
\hline Rat breast cancer line LCM 2388 into rat & 60 IU Epo QW \pm tamoxifen & $\begin{array}{l}\text { No effect Epo alone; increased regression } \\
\text { Epo + tamoxifen }\end{array}$ & Sairah et al ${ }^{356}$ \\
\hline Human squamous cell carcinoma (A43I) & I 50 U/kg Epo TIW & No effect alone; improved RT in anemic mice & Lovey et $\mathrm{al}^{450}$ \\
\hline \multicolumn{4}{|l|}{ No enhanced tumor ablation } \\
\hline Murine MmBI6 melanoma & 20 U Epo BID & No effect alone; no enhanced IL- 12 therapy & Golab et $\mathrm{al}^{451}$ \\
\hline Rat R3230 mammary carcinoma & 2,000 U/kg Epo TIW & No effect alone & Blackwell et al ${ }^{452}$ \\
\hline Rat I3762 mammary adenocarcinoma & $50 \mu g / k g$ Epo TIW & No effect alone & Bianchi et al $\mathrm{a}^{453}$ \\
\hline Rat DS-sarcoma & 1000 U/kg Epo TIW & No effect & Kelleher et a $\left.\right|^{454}$ \\
\hline Rat R3230 mammary carcinoma & $3 \mu g / k g$ DA TIW & No effect to enhance RT & Kirkpatrick et al ${ }^{455}$ \\
\hline Murine C26-B colon adenocarcinoma & 25 U Epo QD to 25 U TIW & No effect on tumor; decreased body weight loss & van Halteren et al $\mathrm{a}^{456}$ \\
\hline Rat R3230 mammary carcinoma, murine & 2000 U/kg Epo TIW & No effect alone & Hardee et $\mathrm{a}^{355}$ \\
\hline
\end{tabular}

CT26 colon carcinoma, human HCT-II6

colon carcinoma, human $\mathrm{FaDu}$ head and neck carcinoma

Rat R3230 mammary carcinoma 2000 U/kg Epo TIW

Human breast carcinomas MDA-MB-23 I and MCF-7

Head and neck squamous cell carcinoma LU-HNxSCX-7

Human breast MCF-7, renal 786-0, gastric SCH, lung A549, ovary SK-OV-3 tumor cell lines into mice

Murine BI6FI0 melanoma Human glioblastoma U87 Human breast MDA453 $\beta$ and MCF7-HERI 8 (engineered)

\section{Promoted tumor growth}

Murine MCA-induced fibrosarcoma

Murine colorectal cancer cells in $50 \%$ hepatectomized mice
$2.5 \mathrm{mg} / \mathrm{kg}$ epoetin- $\alpha, 7.5$

$\mathrm{mg} / \mathrm{kg} \mathrm{DA}$, and $2.5 \mathrm{mg} / \mathrm{kg}$ epoetin- $\beta$

$400 \mathrm{U} / \mathrm{kg}$ epoetin- $\beta$ Q3D

1000,3000 , or $10,000 \mathrm{IU} / \mathrm{kg}$

epoetin- $\beta$ QW

$30 \mathrm{mg} / \mathrm{kg}$ DA QW

$5000 \mathrm{U} / \mathrm{kg}$ Epo TIW

$100 \mathrm{U}$ rHuEpo daily

(weekdays)

$100 \mathrm{IU} / \mathrm{kg}$ Epo QW

$10 \mathrm{mg} / \mathrm{kg}$ DA once
No effect alone; no enhanced CT

No effect alone; no enhanced CT

in either model

No effect alone; slight increased tumor

growth with surgical transection

No effect alone; no enhanced effect on

bevacizumab on A549 and MCF-7 (avastin)

No effect alone

No effect alone

No effect alone; antagonized trastuzumab

effect on tumor regression

Epo promoted tumor growth

Increased tumor growth after hepatectomy
Hardee et $\mathrm{al}^{457}$

LaMontagne et al $^{300}$

Kjellen et $\mathrm{al}^{458}$

Kataoka et $\mathrm{al}^{223}$

Miller et $\mathrm{a}^{307}$

Hassouna et al ${ }^{299}$

Liang et $\mathrm{al}^{275}$

Okazaki et al ${ }^{459}$

Rupertus et $\mathrm{al}^{460}$

Abbreviations: TIW, three times per week; BID, twice per day; QD, once daily; QW, once per week; Q2W, every two weeks; Q3D, every three days; RT, radiotherapy; $\mathrm{CT}$, chemotherapy; PT, photodynamic therapy; DA, darbepoetin alfa; Epo, erythropoietin.

Consistent with this possibility, some erythroleukemia cells were reported to express Epo B15,316 $^{3}$ and Epo was reported to support their growth. ${ }^{317}$ Erythrocytosis is observed in some patients with renal carcinomas, liver carcinomas, in Wilms' tumors and cerebellar hemangioblastomas. ${ }^{47,48,318-320}$ In VHL syndrome patients that contain pVHL mutations, paraneoplastic Epo production and erythrocytosis is associated with renal carcinoma, cysts, cerebellar hemangioblastoma, and 
pheochromocytoma. ${ }^{321}$ However, in many of these cases, it is likely that Epo production is secondary to activation of the HIF pathway, or alternatively, secondary to tumor formation in cell types that normally produce Epo (eg, hepatocytes). Alternatively, tumors may produce other substances that can synergise with Epo and promote erythropoiesis, such as thyroid hormone, glucocorticoids, SCF, IL-3, or GM-CSF.

The possibility that tumors express both Epo and EpoR and that this is a driver of their growth is not supported by other data. Indeed, anemia and not erythrocytosis is a general characteristic of patients with solid tumors, suggesting that most tumor cells do not express significant amounts of Epo. Several groups reported that an Epo-EpoR cytokine loop is not a general property of tumors. ${ }^{80,322}$ Forced expression of Epo in mouse erythroid cells, using a human EPO gene under the control of a human $\beta$-globin locus control regulatory element, resulted in autocrine stimulation of erythropoiesis and erythrocytosis in transgenic mice. However, those mice did not develop erythroleukemia. ${ }^{45}$ Similarly, constitutive Epo expression in the bone marrow of mice using retroviral vectors with EPOR expression cassettes resulted in erythrocytosis but not erythroleukemia, ${ }^{45}$ and Epo gene therapy in mice did not result in tumors when Epo was overproduced. ${ }^{323,324}$

The suggestion that tumor cells may express Epo at levels sufficient to activate resident EpoR is based almost exclusively on IHC experiments on tumor sections or Western immunoblot analysis on tumor cells using nonvalidated anti-Epo polyclonal antibodies. In the kidney, where Epo is expressed at relatively high levels, Epo is secreted efficiently, resulting in very low intracellular stores. Consequently, attempts to identify the Epo-producing cell type by IHC with anti-Epo antibodies would be difficult and have been unsuccessful. ${ }^{16,51}$ This indicates that it would be even more difficult to detect Epo in tissue sections that have even lower Epo expression levels than in the kidney. ${ }^{50}$ In addition, similar to anti-EpoR antibodies, many available anti-Epo antibodies used by investigators are also nonspecific (Amgen, unpublished data) raising further questions about the significance of positive IHC or Western data with anti-Epo antibodies.

\section{Epo and angiogenesis}

Blood vessel development consists of two distinct phases vasculogenesis and angiogenesis. Vasculogenesis is the assembly of vessels de novo and angiogenesis arises through the proliferation, movement, and incorporation of endothelial cells into existing vessels. ${ }^{325}$ Given the important role that Epo and EpoR play in regulating oxygen delivery, hypothetically Epo may also play a role in regulating blood flow through effects on the endothelium or through stimulation of blood vessel formation. Supporting this possibility, in EpoR and Epo knockout mouse embryos, though de novo vasculogenesis remained intact, ${ }^{326,327}$ a defect in angiogenesis was reported. Positive effects of Epo on vasculogenesis or angiogenesis using bone marrow-derived endothelial progenitor cells (EPCs) in vitro and in vivo have also been reported by some groups, ${ }^{328-332}$ but positive effects were not observed by others. ${ }^{333-336}$ ESAs have been reported to increase circulating levels of EPCs, ${ }^{337-341}$ and in the case of a subject with erythrocytosis caused by a mutation in EpoR resulting in hypersensitivity to Epo, there were increased levels of circulating EPCs. ${ }^{342}$ However, interpretation of some of this positive data can be confusing, because a surface marker found on endothelial cells (endoglin: CD105) ${ }^{343}$ is also expressed on erythroid cells, ${ }^{343,344}$ resulting in possible false-positive identification of EPCs with that marker.

In contrast to the data described above, there are other reports that ESAs did not affect the vasculature. For example, rHuEpo did not affect endothelial progenitor levels ${ }^{345,346}$ or endothelial markers in patients receiving hemodialysis in clinical studies, ${ }^{347}$ and Epo did not recruit BM-derived endothelial progenitor cells in BM-transplanted mice to neointima in arteries with wire-induced injury despite accelerating reendothelialization. ${ }^{348}$ Further confounding the data are other studies suggesting BM-derived endothelial progenitor cells do not contribute to the vasculature. ${ }^{349,350}$ These included a study where $E p o R^{-/}$mice had normal vascular endothelium, ${ }^{38}$ as did $E p o R^{-/}$mice crossed with transgenic mice where EpoR expression was restricted to the erythroid compartment. ${ }^{351}$ Therefore, if EPCs do not even contribute to the vasculature, the role of Epo itself in possibly mobilizing the EPC becomes irrelevant. These conflicting studies raise questions about the significance of reports that ESAs affect endothelial progenitors.

In several independent studies, endothelial cells were reported neither to express significant levels of EpoR nor to respond to ESAs. In one study using a specific anti-EpoR antibody, A82, endothelial cell preparations expressed very low levels of total EpoR protein, with no detectable protein on the cell surface and no response to ESAs in vitro. ${ }^{94}$ In other studies, $\mathrm{rHuEpo}$ had no effect on endothelial cell preparations in controlled in vitro and in vivo experiments. ${ }^{94,352-354}$ In tumor xenograft studies, no effect on angiogenesis was observed when animals were administered ESAs. ${ }^{355-357}$

While several groups have reported that EpoR was present in endothelial cell preparations, the studies were based on the detection of EpoR using anti-EpoR antibodies that suffered from the same antibody nonspecificity issues described above. In ESA response studies, effects were only observed at 
supraphysiologic and suprapharmacologic levels of rHuEpo $(>10 \mathrm{U} / \mathrm{mL})$, a concentration which may be more prone to provide false-positive results. Some groups reported that $\left[{ }^{125} \mathrm{I}\right] \mathrm{rHuEpo}$ bound to endothelial cell preparations, ${ }^{129,358,359}$ but the binding properties included unusually high EpoR density and low affinity, characteristics more consistent with nonspecific or off-target binding. ${ }^{268}$ Further, the high EpoR density reported did not correlate with the relatively low EpoR transcript levels or EpoR protein levels detected by Western analysis with a specific anti-EpoR antibody. ${ }^{94}$ Increased thymidine incorporation into brain capillary endothelial cells following addition of rHuEpo was reported in one study, but only if the addition was accompanied by a change in growth medium, ${ }^{358}$ raising concerns about potential artifacts. Artifact was most likely the reason that rHuEpo reportedly induced increased vascularization in chicken eggs (chick chorioallantoic membrane assay), ${ }^{337,360,361}$ because there is no evidence of cross-species activity between human Epo and chicken EpoR. ${ }^{362-364}$

\section{Cytoprotective effect of Epo on normal nonhematopoietic cells and tissues}

In addition to erythropoietic defects in Epo or EpoR knockout mice, nonhematopoietic developmental defects in the heart and vasculature were also reported, suggesting a functional role for Epo-EpoR in those organs. ${ }^{326,365}$ This possibility was further evaluated in transgenic mice with EpoR expression limited to the hematopoietic compartment using a GATA-1 promoter linked to the EpoR gene. ${ }^{351}$ Though the GATA1-EpoR transgenic mice had no detectable EpoR mRNA expression outside the erythroid compartment using RT-PCR analysis, the mice developed normally and had normal organ function and vasculature. These data suggested that EpoR was not required for normal nonhematopoietic organ development, and that reported nonhematopoietic effects may have been mediated though indirect mechanisms, such as insufficient oxygen delivery due to the defect in erythropoiesis.

Cytoprotection studies in animals have been performed to evaluate the possibility that ESAs have nonhematopoietic effects. Overall, in a number of different animal studies (rodents, pigs, rabbits), ESAs were reported to enhance angiogenesis after injury in models of hypoxia-induced hypertension $^{366}$ and peripheral hind limb ischemia, ${ }^{367}$ and reduce tissue injury in heart, ${ }^{368-374}$ brain, ${ }^{375-377}$ kidney, ${ }^{378,379}$ and other organs $s^{204,367,380-383}$ using different injury model systems. Though these data suggest that ESAs have direct effects on nonhematopoietic tissues, the positive findings from these studies may be related to RBC increases, such as enhanced oxygen delivery or changes in ferrokinetics. ${ }^{384}$ In the particular case of neuroprotection by ESAs, cerebrospinal fluid (CSF) Epo levels did not correlate with plasma Epo levels, ${ }^{385}$ ESAs were not transported into the brain at significant levels, ${ }^{386}$ and even though there was some increase in CSF levels of Epo where there was blood-brain barrier dysfunction, Epo concentrations were still very low $^{385,387}$ (1-3 mU/mL vs 10-30 in serum), raising questions about possible direct effects of ESA addition on brain function in animal or human studies.

In a conditional EpoR knockout study in mice with brain-specific inactivation of the EpoR gene, endogenous Epo-EpoR was found nonessential for protecting neurons from ischemic injury, though a role was suggested in poststroke neurogenesis. ${ }^{388}$ In this study, mice with no EpoR expression in the brain had a slight reduction in proliferation and migration of neuroblasts to the peri-infarct cortex. A similar role of endogenous Epo-EpoR was suggested using another conditional EpoR knockout system. ${ }^{389}$ In the absence of neural EpoR, a twofold increase in neural cell apoptosis and a two- to threefold decrease in neural progenitor cell proliferation compared to wild type was reported. However, the functional neurological impact of the findings in these two studies was not reported.

Although ESAs were reported to have cytoprotective activities by directly interacting with EpoR present on cells, the data supporting this hypothesis are confounded by a number of issues similar to those associated with the hypothesis that ESAs directly stimulate tumor cells. Some investigators reported EpoR mRNA was expressed in nonerythroid tissues and suggested functional EpoR protein may also be present. ${ }^{176,286,358,365,370,389-392}$ However, EpoR mRNA levels in nonhematopoietic tissues were 5-1000 times lower than in bone marrow (see also Figure 3), and detection of EpoR mRNA in cell lines and endothelial cells did not predict surface expression. ${ }^{94}$ Many of the investigators that reported EpoR protein expression in normal nonhematopoietic tissues ${ }^{390,391,393}$ used antibodies known to be nonspecific, most likely resulting in false-positive results. ${ }^{76,91,97,98,248,249,394}$ Alternative approaches to determine surface protein, such as radiolabeled [ [ $\left.{ }^{125} \mathrm{I}\right] \mathrm{rHuEpo}$ binding studies, found EpoR characteristics (high receptor number, low affinity) that are substantially different from EpoR characteristics on erythroid progenitor cells (low receptor number, high affinity). ${ }^{11,129,235,358,359,391}$ Recently, results using a specific anti-EpoR antibody (A82) indicated that EpoR was undetectable in most nonhematopoietic tissues from humans and mice (see Figure 4), raising further questions about the 
potential for ESAs to have a direct effect on nonhematopoietic tissues. ${ }^{94,255}$

ESAs were reported to activate downstream antiapoptotic signaling pathways in nonhematopoietic tissues, a mechanism that could inhibit cell death associated with tissue insult (eg, ischemia, reperfusion injury, and exposure to cytotoxins) in vitro. ${ }^{369,372,375,376,389}$ For example, rHuEpo was reported to activate AKT and ERK signaling in cardiac myocytes in vitro, reducing apoptosis by $\sim 30 \%$ upon exposure to hydrogen peroxide. ${ }^{395}$ In studies evaluating the effects of ESAs on nonhematopoietic cell proliferation, signaling, or inhibition of apoptosis, modest effects (two- to threefold increases that are within the experimental noise of the system) were reported. ${ }^{368,375,378,395,396}$ Many of these studies used cells starved of serum and did not describe the use of an appropriate vehicle control, both of which raise the possibility of nonspecific effects. ${ }^{286,375,395,397,398}$ Furthermore, rHuEpo doses used for the in vitro studies were approximately tenfold higher $(>10 \mathrm{U} / \mathrm{mL})$ than levels achievable in patients with modest responses reported, raising the possibility of artifacts as well as questions about the physiological and clinical relevance of these findings. ${ }^{286,368,370,378,396,399}$

While the possibility that ESAs may be cytoprotective is supported by some studies, many of the in vivo studies with ESAs are conflicting. For example, though in two studies $\mathrm{rHuEpo}$ reduced ischemia reperfusion-induced renal injury and preserved renal function, ${ }^{400,401}$ in another study rHuEpo did not preserve renal function. ${ }^{402}$ In studies using the same transgenic mouse model of amyotrophic lateral sclerosis, mixed findings have been reported. In one, rHuEpo delayed symptom onset and prolonged survival times. ${ }^{403}$ In a second, rHuEpo delayed disease onset in females but not males, ${ }^{404}$ and in the third, rHuEpo had minimal improvement in motor neuron function, with no effect on motor neuron loss or overall survival. ${ }^{405}$ In another central nervous system (CNS) model, though high doses of rHuEpo (500-5000 U/kg daily) were reported to inhibit CNS inflammatory effects rats with experimental autoimmune encephalomyelitis, ${ }^{406}$ no protective effect was found in animals with adjuvant arthritis, even when the same high-dosing regimen was used. ${ }^{406}$

In other in vivo animal studies, ESAs did not provide nonhematopoietic protective effects. Pretreatment of rats with darbepoetin alfa did not alter endotoxin-evoked myocardial depression or the expression of proapoptotic or antiapoptotic genes in the heart. ${ }^{407}$ rHuEpo was unable to provide neuroprotective effects in a rabbit bacterial meningitis model, even though the systemically administered rHuEpo was reported to penetrate the CNS in infected rabbits. ${ }^{408} \mathrm{rHuEpo}$ was also unable to prevent endotoxinemia-induced liver and kidney damage in rats. ${ }^{408}$ Human clinical studies with tissueprotective end points have also been performed. To date, the cytoprotective effects reported in animal models have generally not translated into a clinical benefit in humans (reviewed in Sølling ${ }^{409}$ ) who had injury to brain, ${ }^{410-412}$ heart, ${ }^{413-419}$ or kidney. ${ }^{420-426}$ Further, in a recent study, rHuEpo had no effect on intracellular signalling with human skeletal muscle. ${ }^{427}$ Taken together, these data suggest that ESAs may not have the broad, reproducible, robust, nonhematopoietic protective abilities described by some investigators.

\section{Alternative receptor complexes for Epo and Epo derivatives}

An alternative receptor complex that can bind ESAs and mediate cytoprotective activity has been proposed based on the unusual binding affinities of ESA reported on nonhematopoietic cells. The proposed alternative receptor was reported to consist of a heteromeric complex of EpoR and the GM-CSF/ IL-3/IL-5 $\beta$-common chain $(\beta c) .{ }^{393}$ It was further proposed that a chemically modified Epo molecule (carbamoylated Epo [cEpo]) bound the alternative receptor complex and provided tissue-protective effects in the absence of stimulation of erythropoiesis. ${ }^{428}$ Similar to rHuEpo, a number of model systems with various cytotoxic insults have been used to describe this cytoprotective activity of cEpo, such as inhibition of cardiacmyocyte apoptosis, ${ }^{393,429}$ improvement in cardiac function after permanent ischemia, ${ }^{429}$ inhibition of renal tubule apoptosis, improvement in renal function after ischemia-reperfusion or obstructive injury, ${ }^{430-432}$ and reduction in neural lesions and apoptosis in the CNS with various rodent model systems. ${ }^{433-435}$ Data used to support the hypothetical cytoprotective role of the $\beta c-E p o R$ heteromer were generated using mice in which the GM-CSF $\beta c$ had been knocked out. Based on these data, cEpo and ESAs were reported to bind to the heteromer, activate signaling pathways, and prevent apoptosis in several normal nonhematopoietic tissues. ${ }^{393,397,428}$ However, this hypothesis is controversial, as other investigators have found $\beta \mathrm{c}$ does not play a role in preventing apoptosis with ESAs. ${ }^{176}$ It is particularly noteworthy that the investigators who initially generated the GM-CSF $\beta c$ knockout mice ${ }^{436}$ examined the receptor status and responsiveness of those animals thoroughly and concluded that there was no evidence of an interaction between the GM-CSF $\beta c$ and EpoR. ${ }^{437-439}$

\section{Summary and conclusions}

Epo is an essential cytokine that binds and activates EpoR resident on the surface of erythroid progenitor cells, thereby 
promoting erythropoiesis. To this end, ESAs are currently indicated for treatment of anemia in patients with chronic kidney disease and chemotherapy-induced anemia. Epo has also been reported to have effects beyond erythropoiesis, such as tissue-protective effects and promotion of tumor cell growth or survival. This Epo-EpoR tumor stimulation hypothesis has been used to explain the safety signals seen in some clinical trails in anemic cancer patients treated with ESAs. However, putative positive results for this hypothesis are generally confounded by the absence of controls to detect false-positive effects and the use of nonspecific reagents in many studies. EpoR levels outside the erythroid compartment are very low, and the data that such low-level EpoR can bind significant amounts of Epo and promote a functional response are unconvincing. Further, in controlled clinical trials, the cytoprotective benefits observed in animal studies have not as yet translated into benefit in the clinic. The totality of evidence suggests that ESAs do not directly stimulate tumor cells and that similarly the cytoprotective and other nonhematopoietic effects of ESA treatment reported are not a direct effect of ESAs acting through EpoR on nonerythroid cells.

\section{Acknowledgments}

The authors thank Chip Stark for guidance on the manuscript.

\section{Disclosure}

Both authors are employees and/or hold stock in Amgen, Inc, a manufacturer of ESAs.

\section{References}

1. Krantz SB. Erythropoietin. Blood. 1991;77(3):419-434.

2. Glaspy J, Crawford J, Vansteenkiste J, et al. Erythropoiesis-stimulating agents in oncology: a study-level meta-analysis of survival and other safety outcomes. Br J Cancer. 2010;102(2):301-315.

3. Bohlius J, Tonia T, Schwarzer G. Twist and shout: one decade of metaanalyses of erythropoiesis-stimulating agents in cancer patients. Acta Haematol. 2010;125(1-2):55-67.

4. Papayannopoulou T, Abkowitz J, D’Andrea A. Biology of erythropoiesis, erythroid maturation and differentiation. In: Hoffman R, Benz EJ, Shattil SJ, et al, editors. Hematology Basic Principals and Practice. 3rd ed. Philadelphia: Churchill Livingston; 2000:202-219.

5. Hunt JA. Half-life and rate of synthesis of globin messenger ribonucleic acid. Determination of half-life of messenger ribonucleic acid and its relative synthetic rate in erythroid cells. Biochem J. 1974;138(3): 487-498.

6. Dev A, Fang J, Sathyanarayana P, Pradeep A, Emerson C, Wojchowski DM. During EPO or anemia challenge, erythroid progenitor cells transit through a selectively expandable proerythroblast pool. Blood. 2010;116(24):5334-5346.

7. Glaser K, Limarzi LR, Poncher HG. Cellular composition of the bone marrow in normal infants and children. Pediatrics. 1950;6(5): 789-824.

8. Sawyer ST, Krantz SB, Goldwasser E. Binding and receptor-mediated endocytosis of erythropoietin in Friend virus-infected erythroid cells. J Biol Chem. 1987;262(12):5554-5562.
9. Migliaccio G, Migliaccio AR, Visser JW. Synergism between erythropoietin and interleukin-3 in the induction of hematopoietic stem cell proliferation and erythroid burst colony formation. Blood. 1988;72(3): 944-951.

10. Backx B, Broeders L, Hoefsloot LH, Wognum B, Lowenberg B. Erythropoiesis in myelodysplastic syndrome: expression of receptors for erythropoietin and kit ligand. Leukemia. 1996;10(3): 466-472.

11. Sawada K, Krantz SB, Dai CH, et al. Purification of human blood burst-forming units-erythroid and demonstration of the evolution of erythropoietin receptors. J Cell Physiol. 1990;142(2):219-230.

12. Smith JA. Exercise, training and red blood cell turnover. Sports Med. 1995;19(1):9-31.

13. Eschbach JW. The anemia of chronic renal failure: pathophysiology and the effects of recombinant erythropoietin. Kidney Int. 1989; 35(1):134-148

14. Law ML, Cai GY, Lin FK, et al. Chromosomal assignment of the human erythropoietin gene and its DNA polymorphism. Proc NatlAcad Sci USA. 1986;83(18):6920-6924.

15. Jacobs K, Shoemaker C, Rudersdorf R, et al. Isolation and characterization of genomic and cDNA clones of human erythropoietin. Nature. 1985;313(6005):806-810

16. LeHir M, Eckardt KU, Kaissling B, Koury ST, Kurtz A. Structurefunction correlations in erythropoietin formation and oxygen sensing in the kidney. Klin Wochenschr. 1991;69(13):567-575.

17. Eschbach JW, Egrie JC, Downing MR, Browne JK, Adamson JW. Correction of the anemia of end-stage renal disease with recombinant human erythropoietin. Results of a combined phase I and II clinical trial. New Engl J Med. 1987;316(2):73-78.

18. Elliott S, Egrie J, Browne J, et al. Control of rHuEPO biological activity: the role of carbohydrate. Exp Hematol. 2004;32(12): 1146-1155.

19. Egrie JC, Strickland TW, Lane J, et al. Characterization and biological effects of recombinant human erythropoietin. Immunobiology. 1986;172(3-5):213-224.

20. Wickrema A, Krantz SB, Winkelmann JC, Bondurant MC. Differentiation and erythropoietin receptor gene expression in human erythroid progenitor cells. Blood. 1992;80(8):1940-1949.

21. Koury MJ, Bondurant MC. Erythropoietin retards DNA breakdown and prevents programmed death in erythroid progenitor cells. Science. 1990;248(4953):378-381

22. Rogers HM, Yu X, Wen J, Smith R, Fibach E, Noguchi CT. Hypoxia alters progression of the erythroid program. Exp Hematol. 2008;36(1): $17-27$.

23. Wang GL, Jiang BH, Rue EA, Semenza GL. Hypoxia-inducible factor 1 is a basic-helix-loop-helix-PAS heterodimer regulated by cellular $\mathrm{O}_{2}$ tension. Proc Natl Acad Sci U S A. 1995;92(12):5510-5514.

24. Jiang BH, Rue E, Wang GL, Roe R, Semenza GL. Dimerization, DNA binding, and transactivation properties of hypoxia-inducible factor 1 . J Biol Chem. 1996;271(30):17771-17778.

25. Rankin EB, Biju MP, Liu Q et al. Hypoxia-inducible factor-2 (HIF-2) regulates hepatic erythropoietin in vivo. J Clin Invest. 2007; 117(4):1068-1077.

26. Yamashita T, Ohneda O, Sakiyama A, Iwata F, Ohneda K, Fujii-Kuriyama Y. The microenvironment for erythropoiesis is regulated by HIF-2alpha through VCAM-1 in endothelial cells. Blood. 2008; 112(4):1482-1492.

27. Kapitsinou PP, Liu Q, Unger TL, et al. Hepatic HIF-2 regulates erythropoietic responses to hypoxia in renal anemia. Blood. 2010; 116(16):3039-3048.

28. Paliege A, Rosenberger C, Bondke A, et al. Hypoxia-inducible factor2alpha-expressing interstitial fibroblasts are the only renal cells that express erythropoietin under hypoxia-inducible factor stabilization. Kidney Int. 2010;77(4):312-318.

29. Epstein AC, Gleadle JM, McNeill LA, et al. C. elegans EGL-9 and mammalian homologs define a family of dioxygenases that regulate HIF by prolyl hydroxylation. Cell. 2001;107(1):43-54. 
30. Masson N, Willam C, Maxwell PH, Pugh CW, Ratcliffe PJ. Independent function of two destruction domains in hypoxia-inducible factor-alpha chains activated by prolyl hydroxylation. EMBO J. 2001;20(18):5197-5206.

31. Bruick RK, McKnight SL. A conserved family of prolyl-4-hydroxylases that modify HIF. Science. 2001;294(5545):1337-1340.

32. Ivan M, Kondo K, Yang H, et al. HIFalpha targeted for VHL-mediated destruction by proline hydroxylation: implications for $\mathrm{O}_{2}$ sensing. Science. 2001;292(5516):464-468.

33. Hon WC, Wilson MI, Harlos K, et al. Structural basis for the recognition of hydroxyproline in HIF-1 alpha by pVHL. Nature. 2002; 417(6892):975-978.

34. Maxwell PH, Pugh CW, Ratcliffe PJ. Insights into the role of the von Hippel-Lindau gene product. A key player in hypoxic regulation. Exp Nephrol. 2001;9(4):235-240.

35. Koury ST, Koury MJ, Bondurant MC, Caro J, Graber SE. Quantitation of erythropoietin-producing cells in kidneys of mice by in situ hybridization: correlation with hematocrit, renal erythropoietin mRNA, and serum erythropoietin concentration. Blood. 1989;74(2):645-651.

36. Obara N, Suzuki N, Kim K, Nagasawa T, Imagawa S, Yamamoto M. Repression via the GATA box is essential for tissue-specific erythropoietin gene expression. Blood. 2008;111(10):5223-5232.

37. Erslev AJ, Wilson J, Caro J. Erythropoietin titers in anemic, nonuremic patients. J Lab Clin Med. 1987;109(4):429-433.

38. Lin CS, Lim SK, D'Agati V, Costantini F. Differential effects of an erythropoietin receptor gene disruption on primitive and definitive erythropoiesis. Genes Dev. 1996;10(2):154-164.

39. Mizuno S, Sasaki J, Suzuki C, Kono H, Kojima S. Effect of recombinant human erythropoietin administration on peripheral blood neutrophil counts of premature infants. J Pediatr. 1994;124(3):467-470.

40. Shannon KM, Mentzer WC, Abels RI, et al. Recombinant human erythropoietin in the anemia of prematurity: results of a placebo-controlled pilot study. J Pediatr. 1991;118(6):949-955.

41. Ward CS, Westwood NB, Emmerson AJ, Pearson TC. The in vitro effect of high-dose recombinant human erythropoietin on granulocyte-macrophage colony production in premature infants using a defined serum deprived cell culture system. Br J Haematol. 1992;81(3):325-330.

42. Ulich TR, del CJ, Yin SM, Egrie JC. The erythropoietic effects of interleukin 6 and erythropoietin in vivo. Exp Hematol. 1991;19(1):29-34.

43. Singbrant S, Russell MR, Jovic T, et al. Erythropoietin couples erythropoiesis, B-lymphopoiesis, and bone homeostasis within the bone marrow microenvironment. Blood. 2011;117(21):5631-5642.

44. Ramsfjell V, Borge OJ, Veiby OP, et al. Thrombopoietin, but not erythropoietin, directly stimulates multilineage growth of primitive murine bone marrow progenitor cells in synergy with early acting cytokines: distinct interactions with the ligands for c-kit and FLT3. Blood. 1996;88(12):4481-4492.

45. Madan A, Lin C, Wang Z, Curtin PT. Autocrine stimulation by erythropoietin in transgenic mice results in erythroid proliferation without neoplastic transformation. Blood Cells Mol Dis. 2003;30(1):82-89.

46. Furukawa T, Narita M, Sakaue M, et al. Primary familial polycythaemia associated with a novel point mutation in the erythropoietin receptor. Br J Haematol. 1997;99(1):222-227.

47. Sherwood JB. The chemistry and physiology of erythropoietin. Vitam Horm. 1984;41:161-211.

48. Jelkmann W. Erythropoietin: structure, control of production, and function. Physiol Rev. 1992;72(2):449-489.

49. Beru N, McDonald J, Lacombe C, Goldwasser E. Expression of the erythropoietin gene. Mol Cell Biol. 1986;6(7):2571-2575.

50. Bachmann S, Le HM, Eckardt KU. Co-localization of erythropoietin mRNA and ecto-5'-nucleotidase immunoreactivity in peritubular cells of rat renal cortex indicates that fibroblasts produce erythropoietin. J Histochem Cytochem. 1993;41(3):335-341.

51. Maxwell PH, Osmond MK, Pugh CW, et al. Identification of the renal erythropoietin-producing cells using transgenic mice. Kidney Int. 1993; 44(5):1149-1162.
52. Tan CC, Eckardt KU, Ratcliffe PJ. Organ distribution of erythropoietin messenger RNA in normal and uremic rats. Kidney Int. 1991;40(1):69-76.

53. Semenza GL, Koury ST, Nejfelt MK, Gearhart JD, Antonarakis SE. Cell-type-specific and hypoxia-inducible expression of the human erythropoietin gene in transgenic mice. Proc Natl Acad Sci U S A. 1991;88(19):8725-8729.

54. Fandrey J, Bunn HF. In vivo and in vitro regulation of erythropoietin mRNA: measurement by competitive polymerase chain reaction. Blood. 1993;81(3):617-623.

55. Suzuki N, Obara N, Yamamoto M. Use of gene-manipulated mice in the study of erythropoietin gene expression. Methods Enzymol. 2007; 435:157-177.

56. David RB, Lim GB, Moritz KM, Koukoulas I, Wintour EM. Quantitation of the mRNA levels of Epo and EpoR in various tissues in the ovine fetus. Mol Cell Endocrinol. 2002;188(1-2):207-218.

57. Bondurant MC, Koury MJ, Koury ST, Semenza G. Erythropoietin ontogeny and organ distribution in mice. Semin Hematol. 1991; 28(3 Suppl 3):20-25.

58. Erslev AJ, Caro J, Kansu E, Silver R. Renal and extrarenal erythropoietin production in anaemic rats. Br J Haematol. 1980;45(1):65-72.

59. Bondurant MC, Koury MJ. Anemia induces accumulation of erythropoietin mRNA in the kidney and liver. Mol Cell Biol. 1986; 6(7):2731-2733.

60. Eckardt KU, Ratcliffe PJ, Tan CC, Bauer C, Kurtz A. Age-dependent expression of the erythropoietin gene in rat liver and kidneys. J Clin Invest. 1992;89(3):753-760.

61. Koury ST, Bondurant MC, Koury MJ, Semenza GL. Localization of cells producing erythropoietin in murine liver by in situ hybridization. Blood. 1991;77(11):2497-2503

62. Frede S, Freitag P, Geuting L, Konietzny R, Fandrey J. Oxygenregulated expression of the erythropoietin gene in the human renal cell line REPC. Blood. 2011;117(18):4905-4914.

63. Loya F, Yang Y, Lin H, Goldwasser E, Albitar M. Transgenic mice carrying the erythropoietin gene promoter linked to lacZ express the reporter in proximal convoluted tubule cells after hypoxia. Blood. 1994;84(6):1831-1836.

64. Jeong JY, Feldman L, Solar P, Szenajch J, Sytkowski AJ. Characterization of erythropoietin receptor and erythropoietin expression and function in human ovarian cancer cells. Int $J$ Cancer. 2008;122(2):274-280.

65. Jeong JY, Hoxhaj G, Socha AL, Sytkowski AJ, Feldman L. An erythropoietin autocrine/paracrine axis modulates the growth and survival of human prostate cancer cells. Mol Cancer Res. 2009;7(7):1150-1157.

66. Acs G, Zhang PJ, Rebbeck TR, Acs P, Verma A. Immunohistochemical expression of erythropoietin and erythropoietin receptor in breast carcinoma. Cancer. 2002;95(5):969-981.

67. Gombos Z, Danihel L, Repiska V, Acs G, Furth E. Expression of erythropoietin and its receptor increases in colonic neoplastic progression: the role of hypoxia in tumorigenesis. Indian J Pathol Microbiol. 2011;54(2):273-278.

68. Sanchez PE, Navarro FP, Fares RP, et al. Erythropoietin receptor expression is concordant with erythropoietin but not with common beta chain expression in the rat brain throughout the life span. J Comp Neurol. 2009;514(4):403-414.

69. Castillo-Melendez M, Yan E, Walker DW. Expression of erythropoietin and its receptor in the brain of late-gestation fetal sheep, and responses to asphyxia caused by umbilical cord occlusion. Dev Neurosci. 2005; 27(2-4):220-227.

70. Chung YH, Kim SI, Joo KM, et al. Age-related changes in erythropoietin immunoreactivity in the cerebral cortex and hippocampus of rats. Brain Res. 2004;1018(1):141-146.

71. Knabe W, Knerlich F, Washausen S, et al. Expression patterns of erythropoietin and its receptor in the developing midbrain. Anat Embryol (Berl). 2004;207(6):503-512.

72. Winkelmann JC, Penny LA, Deaven LL, Forget BG, Jenkins RB. The gene for the human erythropoietin receptor: analysis of the coding sequence and assignment to chromosome 19p. Blood. 1990;76(1):24-30. 
73. Jones SS, D'Andrea AD, Haines LL, Wong GG. Human erythropoietin receptor: cloning, expression, and biologic characterization. Blood. 1990;76(1):31-35.

74. D'Andrea AD, Lodish HF, Wong GG. Expression cloning of the murine erythropoietin receptor. Cell. 1989;57(2):277-285.

75. Budarf M, Huebner K, Emanuel B, et al. Assignment of the erythropoietin receptor (EPOR) gene to mouse chromosome 9 and human chromosome 19. Genomics. 1990;8(3):575-578.

76. Elliott S, Busse L, Bass MB, et al. Anti-Epo receptor antibodies do not predict Epo receptor expression. Blood. 2006;107(5):1892-1895.

77. Atkins HL, Broudy VC, Papayannopoulou T. Characterization of the structure of the erythropoietin receptor by ligand blotting. Blood. 1991;77(12):2577-2582.

78. Elliott S, Busse L, McCaffery I, et al. Identification of a sensitive antierythropoietin receptor monoclonal antibody allows detection of low levels of EpoR in cells. J Immunol Methods. 2010;352:126-139.

79. Ketteler R, Heinrich AC, Offe JK, et al. A functional green fluorescent protein-erythropoietin receptor despite physical separation of JAK2 binding site and tyrosine residues. J Biol Chem. 2002; 277(29):26547-26552.

80. Swift S, Ellison AR, Kassner P, et al. Absence of functional EpoR expression in human tumor cell lines. Blood. 2010;115(21):4254-4263.

81. Neumann D, Wikstrom L, Watowich SS, Lodish HF. Intermediates in degradation of the erythropoietin receptor accumulate and are degraded in lysosomes. J Biol Chem. 1993;268(18):13639-13649.

82. Hilton DJ, Watowich SS, Murray PJ, Lodish HF. Increased cell surface expression and enhanced folding in the endoplasmic reticulum of a mutant erythropoietin receptor. Proc Natl Acad Sci U S A. 1995;92(1):190-194.

83. Supino-Rosin L, Yoshimura A, Altaratz H, Neumann D. A cytosolic domain of the erythropoietin receptor contributes to endoplasmic reticulum-associated degradation. Eur J Biochem. 1999;263(2): $410-419$.

84. Billia F, Barbara M, McEwen J, Trevisan M, Iscove NN. Resolution of pluripotential intermediates in murine hematopoietic differentiation by global complementary DNA amplification from single cells: confirmation of assignments by expression profiling of cytokine receptor transcripts. Blood. 2001;97(8):2257-2268.

85. Liu ZY, Chin K, Noguchi CT. Tissue specific expression of human erythropoietin receptor in transgenic mice. Dev Biol. 1994; 166(1):159-169.

86. Chiba T, Ikawa Y, Todokoro K. GATA-1 transactivates erythropoietin receptor gene, and erythropoietin receptor-mediated signals enhance GATA-1 gene expression. Nucleic Acids Res. 1991;19(14): 3843-3848.

87. Heberlein C, Fischer KD, Stoffel M, et al. The gene for erythropoietin receptor is expressed in multipotential hematopoietic and embryonal stem cells: evidence for differentiation stage-specific regulation. Mol Cell Biol. 1992;12(4):1815-1826.

88. Heinrich AC, Pelanda R, Klingmuller U. A mouse model for visualization and conditional mutations in the erythroid lineage. Blood. 2004;104(3):659-666.

89. Ashihara E, Vannucchi AM, Migliaccio G, Migliaccio AR. Growth factor receptor expression during in vitro differentiation of partially purified populations containing murine stem cells. J Cell Physiol. 1997;171(3):343-356.

90. Chiba S, Takahashi T, Takeshita K, et al. Selective expression of mRNA coding for the truncated form of erythropoietin receptor in hematopoietic cells and its decrease in patients with polycythemia vera. Blood. 1997;90(1):97-104.

91. Laugsch M, Metzen E, Svensson T, Depping R, Jelkmann W. Lack of functional erythropoietin receptors of cancer cell lines. Int $J$ Cancer. 2008;122(5):1005-1011.

92. Sinclair AM, Rogers N, Busse L, et al. Erythropoietin receptor transcription is neither elevated nor predictive of surface expression in human tumour cells. Br J Cancer. 2008;98(6):1059-1067.
93. Keller MA, Addya S, Vadigepalli R, et al. Transcriptional regulatory network analysis of developing human erythroid progenitors reveals patterns of coregulation and potential transcriptional regulators. Physiol Genomics. 2006;28(1):114-128.

94. Sinclair AM, Coxon A, McCaffery I, et al. Functional erythropoietin receptor is undetectable in endothelial, cardiac, neuronal, and renal cells. Blood. 2010;115(21):4264-4272.

95. Hardee ME, Arcasoy MO, Blackwell KL, Kirkpatrick JP, Dewhirst MW. Erythropoietin biology in cancer. Clin Cancer Res. 2006;12(2):332-339.

96. Kokhaei P, Abdalla AO, Hansson L, et al. Expression of erythropoietin receptor and in vitro functional effects of epoetins in B-cell malignancies. Clin Cancer Res. 2007;13(12):3536-3544.

97. Brown WM, Maxwell P, Graham AN, et al. Erythropoietin receptor expression in non-small cell lung carcinoma: a question of antibody specificity. Stem Cells. 2007;25(3):718-722.

98. Kirkeby A, van BJ, Nielsen J, Leist M, Helboe L. Functional and immunochemical characterisation of different antibodies against the erythropoietin receptor. J Neurosci Methods. 2007;164(1):50-58.

99. Sinclair AM, Todd MD, Forsythe K, Knox SJ, Elliott S, Begley CG. Expression and function of erythropoietin receptors in tumors: implications for the use of erythropoiesis-stimulating agents in cancer patients. Cancer. 2007;110(3):477-488.

100. Osterborg A, Aapro M, Cornes P, Haselbeck A, Hayward CR, Jelkmann W. Preclinical studies of erythropoietin receptor expression in tumour cells: impact on clinical use of erythropoietic proteins to correct cancer-related anaemia. Eur J Cancer. 2007;43(3):510-519.

101. Kirkpatrick P. Specificity concerns with antibodies for receptor mapping. Nat Rev Drug Discov. 2009;8(4):278.

102. Bordeaux J, Welsh A, Agarwal S, et al. Antibody validation. Biotechniques. 2010;48(3):197-209.

103. Broudy VC, Lin N, Egrie J, et al. Identification of the receptor for erythropoietin on human and murine erythroleukemia cells and modulation by phorbol ester and dimethyl sulfoxide. Proc Natl Acad Sci USA. 1988;85(17):6513-6517.

104. Broudy VC, Lin N, Brice M, Nakamoto B, Papayannopoulou T. Erythropoietin receptor characteristics on primary human erythroid cells. Blood. 1991;77(12):2583-2590.

105. Radinsky R, Risin S, Fan D, et al. Level and function of epidermal growth factor receptor predict the metastatic potential of human colon carcinoma cells. Clin Cancer Res. 1995;1(1):19-31.

106. Foon KA, Yang XD, Weiner LM, et al. Preclinical and clinical evaluations of ABX-EGF, a fully human anti-epidermal growth factor receptor antibody. Int J Radiat Oncol Biol Phys. 2004;58(3): 984-990.

107. Sasaki R, Yanagawa S, Hitomi K, Chiba H. Characterization of erythropoietin receptor of murine erythroid cells. Eur J Biochem. 1987;168(1):43-48.

108. McArthur GA, Longmore GD, Klingler K, Johnson GR. Lineagerestricted recruitment of immature hematopoietic progenitor cells in response to Epo after normal hematopoietic cell transfection with EpoR. Exp Hematol. 1995;23(7):645-654.

109. Sawada K, Krantz SB, Sawyer ST, Civin CI. Quantitation of specific binding of erythropoietin to human erythroid colony-forming cells. J Cell Physiol. 1988;137(2):337-345.

110. Wognum AW, Lansdorp PM, Humphries RK, Krystal G. Detection and isolation of the erythropoietin receptor using biotinylated erythropoietin. Blood. 1990;76(4):697-705.

111. Wognum AW, Krystal G, Eaves CJ, Eaves AC, Lansdorp PM. Increased erythropoietin-receptor expression on CD34-positive bone marrow cells from patients with chronic myeloid leukemia. Blood. 1992;79(3):642-649.

112. Shinjo K, Takeshita A, Higuchi M, Ohnishi K, Ohno R. Erythropoietin receptor expression on human bone marrow erythroid precursor cells by a newly-devised quantitative flow-cytometric assay. Br J Haematol. 1997;96(3):551-558. 
113. Mayeux P, Billat C, Jacquot R. The erythropoietin receptor of rat erythroid progenitor cells. Characterization and affinity cross-linkage. J Biol Chem. 1987;262(29):13985-13990.

114. Hoshino S, Teramura M, Takahashi M, et al. Expression and characterization of erythropoietin receptors on normal human bone marrow cells. Int J Cell Cloning. 1989;7(3):156-167.

115. Fraser JK, Lin FK, Berridge MV. Expression of high affinity receptors for erythropoietin on human bone marrow cells and on the human erythroleukemic cell line, HEL. Exp Hematol. 1988;16(10): 836-842.

116. Wu H, Liu X, Jaenisch R, Lodish HF. Generation of committed erythroid BFU-E and CFU-E progenitors does not require erythropoietin or the erythropoietin receptor. Cell. 1995;83(1):59-67.

117. Mitjavila MT, Natazawa M, Brignaschi P, Debili N, Breton-Gorius J, Vainchenker W. Effects of five recombinant hematopoietic growth factors on enriched human erythroid progenitors in serum-replaced cultures. J Cell Physiol. 1989;138(3):617-623.

118. Cull V, Tilbrook PA, Adenan AS. Dominant action of mutated erythropoietin receptors on differentiation in vitro and erythroleukemia development in vivo. Oncogene. 2000;19(7):953-960.

119. Huang LJ, Constantinescu SN, Lodish HF. The N-terminal domain of Janus kinase 2 is required for Golgi processing and cell surface expression of erythropoietin receptor. Mol Cell. 2001;8(6):1327-1338.

120. Wickrema A, Bondurant MC, Krantz SB. Abundance and stability of erythropoietin receptor mRNA in mouse erythroid progenitor cells. Blood. 1991;78(9):2269-2275.

121. Lodish HF, Hilton D, Longmore G, Watowich SS, Yoshimura A. The erythropoietin receptor: dimerization, activation, and tumorigenesis. Cold Spring Harb Symp Quant Biol. 1992;57:95-106.

122. Youssoufian H, Zon LI, Orkin SH, D'Andrea AD, Lodish HF. Structure and transcription of the mouse erythropoietin receptor gene. Mol Cell Biol. 1990;10(7):3675-3682.

123. Zon LI, Youssoufian H, Mather C, Lodish HF, Orkin SH. Activation of the erythropoietin receptor promoter by transcription factor GATA-1. Proc Natl Acad Sci U S A. 1991;88(23):10638-10641.

124. Maouche L, Cartron JP, Chretien S. Different domains regulate the human erythropoietin receptor gene transcription. Nucleic Acids Res. 1994;22(3):338-346.

125. Youssoufian H. Further characterization of cis-acting regulatory sequences in the genomic locus of the murine erythropoietin receptor: evidence for stage-specific regulation. Blood. 1994;83(5): 1428-1435.

126. Kuramochi S, Ikawa Y, Todokoro K. Characterization of murine erythropoietin receptor genes. J Mol Biol. 1990;216(3):567-575.

127. Singbrant S, Russell MR, Jovic, et al. Erythropoietin couples erythropoiesis, B lymphopoiesis, and bone homeostasis within the bone marrow microenvironment. Blood. 2011;117(21):5631-5642.

128. Hagstrom L, Agbulut O, El-Hasnaoui-Saadani R, et al. Epo is relevant neither for microvascular formation nor for the new formation and maintenance of mice skeletal muscle fibres in both normoxia and hypoxia. J Biomed Biotechnol. 2010;2010:137817.

129. Banerjee D, Rodriguez M, Nag M, Adamson JW. Exposure of endothelial cells to recombinant human erythropoietin induces nitric oxide synthase activity. Kidney Int. 2000;57(5):1895-1904.

130. Ohigashi T, Yoshioka K, Fisher JW. Autocrine regulation of erythropoietin gene expression in human hepatocellular carcinoma cells. Life Sci. 1996;58(5):421-427.

131. Digicaylioglu M, Bichet S, Marti HH, et al. Localization of specific erythropoietin binding sites in defined areas of the mouse brain. Proc Natl Acad Sci U S A. 1995;92(9):3717-3720.

132. Mohyeldin A, Dalgard CL, Lu H, et al. Survival and invasiveness of astrocytomas promoted by erythropoietin. J Neurosurg. 2007;106(2): 338-350.

133. Bramey T, Freitag P, Fandrey J, et al. No evidence for protective erythropoietin alpha signalling in rat hepatocytes. BMC Gastroenterol. 2009;9:26.
134. Winter SC, Shah KA, Campo L, et al. Relation of erythropoietin and erythropoietin receptor expression to hypoxia and anemia in head and neck squamous cell carcinoma. Clin Cancer Res. 2005;11(21): 7614-7620.

135. Bernaudin M, Bellail A, Marti HH, et al. Neurons and astrocytes express EPO mRNA: oxygen-sensing mechanisms that involve the redox-state of the brain. Glia. 2000;30(3):271-278.

136. Wincewicz A, Koda M, Sulkowska M, Kanczuga-Koda L, Wincewicz D, Sulkowski S. STAT3 and hypoxia induced proteins - HIF-1alpha, EPO and EPOR in relation with Bax and Bcl-xL in nodal metastases of ductal breast cancers. Folia Histochem Cytobiol. 2009;47(3):425-430.

137. Batra S, Perelman N, Luck LR, Shimada H, Malik P. Pediatric tumor cells express erythropoietin and a functional erythropoietin receptor that promotes angiogenesis and tumor cell survival. Lab Invest. 2003; 83(10):1477-1487.

138. Lam SY, Tipoe GL, Fung ML. Upregulation of erythropoietin and its receptor expression in the rat carotid body during chronic and intermittent hypoxia. Adv Exp Med Biol. 2009;648:207-214.

139. Chen ZY, Wang L, Asavaritkrai P, Noguchi CT. Up-regulation of erythropoietin receptor by nitric oxide mediates hypoxia preconditioning. J Neurosci Res. 2010;88(14):3180-3188.

140. Acs G, Acs P, Beckwith SM, et al. Erythropoietin and erythropoietin receptor expression in human cancer. Cancer Res. 2001;61(9): 3561-3565.

141. Pevny L, Lin CS, D’Agati V, Simon MC, Orkin SH, Costantini F. Development of hematopoietic cells lacking transcription factor GATA-1. Development. 1995;121(1):163-172.

142. Pevny L, Simon MC, Robertson E, et al. Erythroid differentiation in chimaeric mice blocked by a targeted mutation in the gene for transcription factor GATA-1. Nature. 1991;349(6306):257-260.

143. Simon MC, Pevny L, Wiles MV, Keller G, Costantini F, Orkin SH. Rescue of erythroid development in gene targeted GATA-1- mouse embryonic stem cells. Nat Genet. 1992;1(2):92-98.

144. Komatsu N, Kirito K, Kashii Y, et al. Cell-cycle-dependent regulation of erythropoietin receptor gene. Blood. 1997;89(4):1182-1188.

145. Suzuki N, Suwabe N, Ohneda O, et al. Identification and characterization of 2 types of erythroid progenitors that express GATA-1 at distinct levels. Blood. 2003;102(10):3575-3583.

146. Crotta S, Nicolis S, Ronchi A, et al. Progressive inactivation of the expression of an erythroid transcriptional factor in GM- and G-CSF-dependent myeloid cell lines. Nucleic Acids Res. 1990;18(23):6863-6869.

147. Migliaccio AR, Migliaccio G, D’Andrea A, et al. Response to erythropoietin in erythroid subclones of the factor-dependent cell line $32 \mathrm{D}$ is determined by translocation of the erythropoietin receptor to the cell surface. Proc Natl Acad Sci U S A 1991;88(24): 11086-11090.

148. Tsang AP, Fujiwara Y, Hom DB, Orkin SH. Failure of megakaryopoiesis and arrested erythropoiesis in mice lacking the GATA-1 transcriptional cofactor FOG. Genes Dev. 1998;12(8):1176-1188.

149. Snow JW, Orkin SH. Translational isoforms of FOG1 regulate GATA1interacting complexes. J Biol Chem. 2009;284(43):29310-29319.

150. Kassouf MT, Hughes JR, Taylor S, et al. Genome-wide identification of TAL1's functional targets: insights into its mechanisms of action in primary erythroid cells. Genome Res. 2010;20(8):1064-1083.

151. Mikkola HK, Klintman J, Yang H, et al. Haematopoietic stem cells retain long-term repopulating activity and multipotency in the absence of stem-cell leukaemia SCL/tal-1 gene. Nature. 2003; 421(6922):547-551.

152. Green AR, Salvaris E, Begley CG. Erythroid expression of the 'helixloop-helix' gene, SCL. Oncogene. 1991;6(3):475-479.

153. Visvader J, Begley CG, Adams JM. Differential expression of the LYL, SCL and E2 A helix-loop-helix genes within the hemopoietic system. Oncogene. 1991;6(2):187-194.

154. Inthal A, Krapf G, Beck D, et al. Role of the erythropoietin receptor in ETV6/RUNX1-positive acute lymphoblastic leukemia. Clin Cancer Res. 2008;14(22):7196-7204. 
155. Green AR, Lints T, Visvader J, Harvey R, Begley CG. SCL is coexpressed with GATA-1 in hemopoietic cells but is also expressed in developing brain. Oncogene. 1992;7(4):653-660.

156. Maouche L, Cartron JP, Chretien S. Different domains regulate the human erythropoietin receptor gene transcription. Nucleic Acids Res. 1994;22(3):338-346.

157. Noguchi CT, Bae KS, Chin K, Wada Y, Schechter AN, Hankins WD. Cloning of the human erythropoietin receptor gene. Blood. 1991; 78(10):2548-2556.

158. Philo JS, Aoki KH, Arakawa T, Narhi LO, Wen J. Dimerization of the extracellular domain of the erythropoietin (EPO) receptor by EPO: one high-affinity and one low-affinity interaction. Biochemistry. 1996; 35(5):1681-1691.

159. Syed RS, Reid SW, Li C, et al. Efficiency of signalling through cytokine receptors depends critically on receptor orientation. Nature. 1998;395(6701):511-516.

160. Watowich SS. Activation of erythropoietin signaling by receptor dimerization. Int J Biochem Cell Biol. 1999;31(10):1075-1088.

161. Gross AW, Lodish HF. Cellular trafficking and degradation of erythropoietin and novel erythropoiesis stimulating protein (NESP). J Biol Chem. 2006;281(4):2024-2032.

162. Beckman DL, Lin LL, Quinones ME, Longmore GD. Activation of the erythropoietin receptor is not required for internalization of bound erythropoietin. Blood. 1999;94(8):2667-2675

163. Narhi LO, Aoki KH, Philo JS, Arakawa T. Changes in conformation and stability upon formation of complexes of erythropoietin (EPO) and soluble EPO receptor. J Protein Chem. 1997;16(3): 213-225.

164. Remy I, Wilson IA, Michnick SW. Erythropoietin receptor activation by a ligand-induced conformation change. Science. 1999; 283(5404):990-993.

165. Lu X, Gross AW, Lodish HF. Active conformation of the erythropoietin receptor: random and cysteine-scanning mutagenesis of the extracellular juxtamembrane and transmembrane domains. $J$ Biol Chem. 2006;281(11):7002-7011.

166. Wojchowski DM, Gregory RC, Miller CP, Pandit AK, Pircher TJ. Signal transduction in the erythropoietin receptor system. Exp Cell Res. 1999;253(1):143-156.

167. Jegalian AG, Wu H. Differential roles of SOCS family members in EpoR signal transduction. J Interferon Cytokine Res. 2002; 22(8):853-860

168. Minoo P, Zadeh MM, Rottapel R, Lebrun JJ, Ali S. A novel SHP-1/ Grb2-dependent mechanism of negative regulation of cytokinereceptor signaling: contribution of SHP-1 C-terminal tyrosines in cytokine signaling. Blood. 2004;103(4):1398-1407.

169. Verdier F, Walrafen $P$, Hubert N, et al. Proteasomes regulate the duration of erythropoietin receptor activation by controlling downregulation of cell surface receptors. J Biol Chem. 2000;275(24): 18375-18381.

170. Kubatzky KF, Ruan W, Gurezka R, et al. Self assembly of the transmembrane domain promotes signal transduction through the erythropoietin receptor. Curr Biol. 2001;11(2):110-115.

171. Binder C, Lafayette A, Archibeque I, et al. Optimization and utilization of the SureFire phospho-STAT5 assay for a cell-based screening campaign. Assay Drug Dev Technol. 2008;6(1):27-37.

172. Takahashi T, Chiba S, Hirano N, Yazaki Y, Hirai H. Characterization of three erythropoietin (Epo)-binding proteins in various human Eporesponsive cell lines and in cells transfected with human Epo-receptor cDNA. Blood. 1995;85(1):106-114.

173. Santucci MA, Pierce JH, Zannini S, et al. Erythropoietin increases the radioresistance of a clonal hematopoietic progenitor cell line expressing a transgene for the erythropoietin receptor. Stem Cells. 1994;12(5):506-513.

174. Yawata H, Yasukawa K, Natsuka S, et al. Structure-function analysis of human IL-6 receptor: dissociation of amino acid residues required for IL-6-binding and for IL-6 signal transduction through gp130. EMBOJ. 1993;12(4):1705-1712.
175. Jegalian AG, Acurio A, Dranoff G, Wu H. Erythropoietin receptor haploinsufficiency and in vivo interplay with granulocytemacrophage colony-stimulating factor and interleukin 3. Blood. 2002;99(7):2603-2605.

176. Um M, Gross AW, Lodish HF. A “classical” homodimeric erythropoietin receptor is essential for the antiapoptotic effects of erythropoietin on differentiated neuroblastoma SH-SY5Y and pheochromocytoma PC-12 cells. Cell Signal. 2007;19(3):634-645.

177. Pregi N, Vittori D, Perez G, Leiros CP, Nesse A. Effect of erythropoietin on staurosporine-induced apoptosis and differentiation of SH-SY5Y neuroblastoma cells. Biochim Biophys Acta. 2006; 1763(2):238-246.

178. Rossler J, Stolze I, Frede S, et al. Hypoxia-induced erythropoietin expression in human neuroblastoma requires a methylation free HIF-1 binding site. J Cell Biochem. 2004;93(1):153-161.

179. Drexler HG, Matsuo Y, MacLeod RA. Malignant hematopoietic cell lines: in vitro models for the study of erythroleukemia. Leuk Res. 2004;28(12):1243-1251.

180. Todokoro K, Kanazawa S, Amanuma H, Ikawa Y. Characterization of erythropoietin receptor on erythropoietin-unresponsive mouse erythroleukemia cells. Biochim Biophys Acta. 1988;943(2): 326-330.

181. Mayeux P, Billat C, Jacquot R. Murine erythroleukaemia cells (Friend cells) possess high-affinity binding sites for erythropoietin. FEBS Lett. 1987;211(2):229-233.

182. Ehrenman K, St JT. The erythropoietin receptor gene: cloning and identification of multiple transcripts in an erythroid cell line OCIM1. Exp Hematol. 1991;19(9):973-977.

183. Zou X, Calame K. Signaling pathways activated by oncogenic forms of Abl tyrosine kinase. J Biol Chem. 1999;274(26):18141-18144.

184. Lozzio CB, Lozzio BB. Human chronic myelogenous leukemia cell-line with positive Philadelphia chromosome. Blood. 1975;45(3): 321-334.

185. Elliott S, Busse L, Swift S, et al. Lack of expression and function of erythropoietin receptors in kidney. Nephrol Dial Transplant. 2012. Epub December 13, 2011.

186. Gaffen SL, Lai SY, Longmore GD, Liu KD, Goldsmith MA. Genetic evidence for an additional factor required for erythropoietin-induced signal transduction. Blood. 1999;94(1):74-86.

187. D'Andrea AD, Jones SS. Activation of the erythropoietin receptor in stable lymphoid and myeloid transfectants. Semin Hematol. 1991; 28(2):152-157.

188. Shikama Y, Barber DL, D'Andrea AD, Sieff CA. A constitutively activated chimeric cytokine receptor confers factor-independent growth in hematopoietic cell lines. Blood. 1996;88(2):455-464.

189. Wakao H, Harada N, Kitamura T, Mui AL, Miyajima A. Interleukin 2 and erythropoietin activate STAT5/MGF via distinct pathways. EMBO J. 1995;14(11):2527-2535.

190. Yamamura Y, Kageyama Y, Matuzaki T, Noda M, Ikawa Y. Distinct downstream signaling mechanism between erythropoietin receptor and interleukin-2 receptor. EMBO J. 1992;11(13):4909-4915.

191. Minamoto S, Treisman J, Hankins WD, Sugamura K, Rosenberg SA. Acquired erythropoietin responsiveness of interleukin-2dependent $\mathrm{T}$ lymphocytes retrovirally transduced with genes encoding chimeric erythropoietin/interleukin-2 receptors. Blood. 1995;86(6):2281-2287.

192. Longmore GD, Lodish HF. An activating mutation in the murine erythropoietin receptor induces erythroleukemia in mice: a cytokine receptor superfamily oncogene. Cell. 1991;67(6):1089-1102.

193. Kang JK, Chang CH, Nam HJ, et al. Downregulation of erythropoietin receptor by overexpression of phospholipase C-gamma 1 is critical for decrease on focal adhesion in transformed cells. Cell Oncol. 2011;34(1):11-21.

194. Layon ME, Ackley CJ, West RJ, Lowrey CH. Expression of GATA-1 in a non-hematopoietic cell line induces beta-globin locus control region chromatin structure remodeling and an erythroid pattern of gene expression. J Mol Biol. 2007;366(3):737-744. 
195. Miura Y, Miura O, Ihle JN, Aoki N. Activation of the mitogenactivated protein kinase pathway by the erythropoietin receptor. J Biol Chem. 1994;269(47):29962-29969.

196. Zhan X, Goldfarb M. Growth factor requirements of oncogenetransformed NIH $3 \mathrm{~T} 3$ and BALB/c $3 \mathrm{~T} 3$ cells cultured in defined media. Mol Cell Biol. 1986;6(10):3541-3544.

197. Pharr PN, Ogawa M, Hofbauer A, Longmore GD. Expression of an activated erythropoietin or a colony-stimulating factor 1 receptor by pluripotent progenitors enhances colony formation but does not induce differentiation. Proc Natl Acad Sci U S A. 1994;91(16):7482-7486.

198. Longmore GD, Pharr P, Neumann D, Lodish HF. Both megakaryocytopoiesis and erythropoiesis are induced in mice infected with a retrovirus expressing an oncogenic erythropoietin receptor. Blood. 1993;82(8):2386-2395

199. Longmore GD, Pharr PN, Lodish HF. A constitutively activated erythropoietin receptor stimulates proliferation and contributes to transformation of multipotent, committed nonerythroid and erythroid progenitor cells. Mol Cell Biol. 1994;14(4):2266-2277.

200. Henke M, Laszig R, Rube C, et al. Erythropoietin to treat head and neck cancer patients with anaemia undergoing radiotherapy: randomised, double-blind, placebo-controlled trial. Lancet. 2003 ; 362(9392):1255-1260.

201. Henke M, Mattern D, Pepe M, et al. Do erythropoietin receptors on cancer cells explain unexpected clinical findings? J Clin Oncol 2006;24(29):4708-4713.

202. McKinney M, Arcasoy MO. Erythropoietin for oncology supportive care. Exp Cell Res. 2011;317(9 Special Issue SI):1246-1254.

203. Szenajch J, Wcislo G, Jeong JY, Szczylik C, Feldman L. The role of erythropoietin and its receptor in growth, survival and therapeutic response of human tumor cells. From clinic to bench - a critical review. Biochim Biophys Acta. 2010;1806(1):82-95.

204. Jelkmann W, Bohlius J, Hallek M, Sytkowski AJ. The erythropoietin receptor in normal and cancer tissues. Crit Rev Oncol Hematol. 2008;67(1):39-61.

205. Nowrousian MR, Dunst J, Vaupel P. Erythropoiesis-stimulating agents: favorable safety profile when used as indicated. Strahlenther Onkol. 2008;184(3):121-136.

206. Hadland BK, Longmore GD. Erythroid-stimulating agents in cancer therapy: potential dangers and biologic mechanisms. J Clin Oncol 2009;(25):4217-4226.

207. Winkelmann JC, Ward J, Mayeux P, Lacombe C, Schimmenti L, Jenkins RB. A translocated erythropoietin receptor gene in a human erythroleukemia cell line (TF-1) expresses an abnormal transcript and a truncated protein. Blood. 1995;85(1):179-185.

208. Chretien S, Moreau-Gachelin F, Apiou F, et al. Putative oncogenic role of the erythropoietin receptor in murine and human erythroleukemia cells. Blood. 1994;83(7):1813-1821.

209. Gonda TJ, D’Andrea RJ. Activating mutations in cytokine receptors: implications for receptor function and role in disease. Blood 1997;89(2):355-369.

210. Le Couedic JP, Mitjavila MT, Villeval JL, et al. Missense mutation of the erythropoietin receptor is a rare event in human erythroid malignancies. Blood. 1996;87(4):1502-1511.

211. D'Andrea AD, Moreau JF, Showers MO. Molecular mimicry of erythropoietin by the spleen focus-forming virus gp55 glycoprotein: the first stage of Friend virus-induced erythroleukemia. Biochim Biophys Acta. 1992;1114(1):31-41.

212. Moreau-Gachelin F. Multi-stage Friend murine erythroleukemia: molecular insights into oncogenic cooperation. Retrovirology 2008;5:99.

213. Yoshimura A, Longmore G, Lodish HF. Point mutation in the exoplasmic domain of the erythropoietin receptor resulting in hormone-independent activation and tumorigenicity. Nature. 1990; 348(6302):647-649.

214. Rives S, Pahl HL, Florensa L, et al. Molecular genetic analyses in familial and sporadic congenital primary erythrocytosis. Haematologica. 2007;92(5):674-677.
215. Al-Sheikh M, Mazurier E, Gardie B, et al. A study of 36 unrelated cases with pure erythrocytosis revealed three new mutations in the erythropoietin receptor gene. Haematologica. 2008;93(7):1072-1075.

216. Watowich SS, Xie X, Klingmuller U, et al. Erythropoietin receptor mutations associated with familial erythrocytosis cause hypersensitivity to erythropoietin in the heterozygous state. Blood. 1999; 94(7):2530-2532.

217. de la Chapelle A, Traskelin AL, Juvonen E. Truncated erythropoietin receptor causes dominantly inherited benign human erythrocytosis. Proc Natl Acad Sci U S A. 1993;90(10):4495-4499.

218. Gordeuk VR, Sergueeva AI, Miasnikova GY, et al. Congenital disorder of oxygen sensing: association of the homozygous Chuvash polycythemia VHL mutation with thrombosis and vascular abnormalities but not tumors. Blood. 2004;103(10):3924-3932.

219. Acs G, Zhang PJ, McGrath CM, et al. Hypoxia-inducible erythropoietin signaling in squamous dysplasia and squamous cell carcinoma of the uterine cervix and its potential role in cervical carcinogenesis and tumor progression. Am J Pathol. 2003;162(6): 1789-1806.

220. Arcasoy MO, Jiang X, Haroon ZA. Expression of erythropoietin receptor splice variants in human cancer. Biochem Biophys Res Commun. 2003;307(4):999-1007.

221. Batra S, Perelman N, Luck LR, Shimada H, Malik P. Pediatric tumor cells express erythropoietin and a functional erythropoietin receptor that promotes angiogenesis and tumor cell survival. Lab Invest. 2003;83(10):1477-1487.

222. Feldman L, Wang Y, Rhim JS, Bhattacharya N, Loda M, Sytkowski AJ. Erythropoietin stimulates growth and STAT5 phosphorylation in human prostate epithelial and prostate cancer cells. Prostate. 2006;66(2):135-145.

223. Kataoka M, Moriya Y, Moriguchi Y, et al. Effect of erythropoietin on human tumor growth in xenograft models. Mol Med Report. 2010;3(1):95-101.

224. Lai SY, Childs EE, Xi S, et al. Erythropoietin-mediated activation of JAK-STAT signaling contributes to cellular invasion in head and neck squamous cell carcinoma. Oncogene. 2005;24(27): 4442-4449.

225. Larsson AM, Jirstrom K, Fredlund E, et al. Erythropoietin receptor expression and correlation to tamoxifen response and prognosis in breast cancer. Clin Cancer Res. 2009;15(17):5552-5559.

226. Westphal G, Niederberger E, Blum C, et al. Erythropoietin and G-CSF receptors in human tumor cells: expression and aspects regarding functionality. Tumori. 2002;88(2):150-159.

227. Yasuda Y, Fujita Y, Matsuo T, et al. Erythropoietin regulates tumour growth of human malignancies. Carcinogenesis. 2003;24(6): 1021-1029.

228. Yasuda Y, Fujita Y, Masuda S, et al. Erythropoietin is involved in growth and angiogenesis in malignant tumours of female reproductive organs. Carcinogenesis. 2002;23(11):1797-1805.

229. Shi Z, Hodges VM, Dunlop EA, et al. Erythropoietin-induced activation of the JAK2/STAT5, PI3K/Akt, and Ras/ERK pathways promotes malignant cell behavior in a modified breast cancer cell line. Mol Cancer Res. 2010;8(4):615-626.

230. Miller CP, lowe KA, Valliant-Saunders K, et al. Evaluating erythropoietin-associated tumor progression using archival tissues from a phase III clinical trial. Stem Cells. 2009;27(9):2353-2361.

231. Ning S, Hartley C, Molineux G, Knox SJ. Darbepoietin alfa potentiates the efficacy of radiation therapy in mice with corrected or uncorrected anemia. Cancer Res. 2005;65(1):284-290.

232. Paragh G, Kumar SM, Rakosy Z, Choi SC, Xu X, Acs G. RNA interference-mediated inhibition of erythropoietin receptor expression suppresses tumor growth and invasiveness in A2780 human ovarian carcinoma cells. Am J Pathol. 2009;174(4):1504-1514.

233. Sasaki Y, Kjellen E, Mineta H, Wennerberg J, Ekblad L. No direct effects of erythropoietin beta on a head and neck squamous cell carcinoma cell line which is growth stimulated in vivo. Acta Oncol. 2009;48(7):1062-1069. 
234. Williams DM, Zimmers TA, Pierce JH, et al. The expression and role of human erythropoietin receptor in erythroid and nonerythroid cells. Ann N Y Acad Sci. 1994;718:232-243.

235. Masuda S, Nagao M, Takahata K, et al. Functional erythropoietin receptor of the cells with neural characteristics. Comparison with receptor properties of erythroid cells. J Biol Chem. 1993;268(15): 11208-11216.

236. Saintigny P, Besse B, Callard P, et al. Erythropoietin and erythropoietin receptor coexpression is associated with poor survival in stage I non-small cell lung cancer. Clin Cancer Res. 2007;13(16): 4825-4831.

237. Belda-Iniesta C, Perona R, Carpeno JC, et al. Human recombinant erythropoietin does not promote cancer growth in presence of functional receptors expressed in cancer cells. Cancer Biol Ther. 2007; 6(10):1600-1605.

238. McBroom JW, Acs G, Rose GS, Krivak TC, Mohyeldin A, Verma A. Erythropoietin receptor function and expression in epithelial ovarian carcinoma. Gynecol Oncol. 2005;99(3):571-577.

239. Rades D, Setter C, Dahl O, Schild SE, Noack F. Prognostic Impact of erythropoietin expression and erythropoietin receptor expression on locoregional control and survival of patients irradiated for stage ii/iii non-small-cell lung cancer. Int J Radiat Oncol Biol Phys. 2011; 80(2):499-505.

240. Rades D, Golke H, Schild SE, Kilic E. The impact of tumor expression of erythropoietin receptors and erythropoietin on clinical outcome of esophageal cancer patients treated with chemoradiation. Int J Radiat Oncol Biol Phys. 2008;71(1):152-159.

241. Ribatti D, Marzullo A, Nico B, Crivellato E, Ria R, Vacca A. Erythropoietin as an angiogenic factor in gastric carcinoma. Histopathology. 2003;42(3):246-250.

242. Ribatti D, Nico B, Perra MT, et al. Erythropoietin is involved in angiogenesis in human primary melanoma. Int J Exp Pathol. 2010; 91(6):495-499.

243. Brunotte J, Bock HC, Bruck W, Hemmerlein B, Strik H. High expression levels of erythropoietin and its receptor are not correlated with shorter survival in human glioblastoma. Exp Ther Med. 2011;2(2): 295-299.

244. Lonnroth C, Svensson M, Wang W, et al. Survival and erythropoietin receptor protein in tumours from patients randomly treated with rhEPO for palliative care. Med Oncol. 2008;25(1):22-29.

245. Mittelbronn M, Capper D, Bunz B, et al. De novo erythropoietin receptor (EPO-R. expression in human neoplastic glial cells decreases with grade of malignancy but is favourably associated with patient survival. Neuropathol Appl Neurobiol. 2007;33(3): 299-307.

246. Pelekanou V, Kampa M, Kafousi M, et al. Erythropoietin and its receptor in breast cancer: correlation with steroid receptors and outcome. Cancer Epidemiol Biomarkers Prev. 2007;16(10):2016-2023.

247. Sartelet H, Fabre M, Castaing M, et al. Expression of erythropoietin and its receptor in neuroblastomas. Cancer. 2007;110(5):1096-1106.

248. Della Ragione F, Cucciolla V, Borriello A, Oliva A, Perrotta S. Erythropoietin receptors on cancer cells: a still open question. J Clin Oncol. 2007;25(13):1812-1813.

249. Sturiale A, Campo S, Crasci E, et al. Erythropoietin and its lost receptor. Nephrol Dial Transplant. 2007;22(5):1484-1485.

250. Lorincz A, Nusser Z. Specificity of immunoreactions: the importance of testing specificity in each method. J Neurosci. 2008;28(37): 9083-9086.

251. Leong AS. Pitfalls in diagnostic immunohistology. Adv Anat Pathol. 2004;11(2):86-93.

252. Bordeaux J, Welsh A, Agarwal S, et al. Antibody validation. Biotechniques. 2010;48(3):197-209.

253. Saper CB. A guide to the perplexed on the specificity of antibodies. J Histochem Cytochem. 2009;57(1):1-5.

254. Fritschy JM. Is my antibody-staining specific? How to deal with pitfalls of immunohistochemistry. Eur J Neurosci. 2008;28(12): 2365-2370.
255. Elliott S, Swift S, Busse L, Rossi J, McCaffery I. Absence of functional Epo receptors in normal and cancerous human tissues and cell lines. Blood. 2011;118(21):3169.

256. Rossi J, McCaffery I, Paweletz K, et al. Analysis of cell surface erythropoietin receptor (EpoR) expression and function in human epithelial tumor tissues [abstract]. J Clin Oncol. 2009;27(15S):Abstr 11104.

257. Takeshita A, Shinjo K, Higuchi M, et al. Quantitative expression of erythropoietin receptor (EPO-R) on acute leukaemia cells: relationships between the amount of EPO-R and CD phenotypes, in vitro proliferative response, the amount of other cytokine receptors and clinical prognosis. Japan Adult Leukaemia Study Group. Br J Haematol. 2000;108(1):55-63.

258. Kokhaei P, Abdalla AO, Hansson L, et al. Expression of erythropoietin receptor and in vitro functional effects of epoetins in B-cell malignancies. Clin Cancer Res. 2007;13(12):3536-3544.

259. LaMontagne KR, Butler J, Marshall DJ, et al. Recombinant epoetins do not stimulate tumor growth in erythropoietin receptor-positive breast carcinoma models. Mol Cancer Ther. 2006;5(2):347-355.

260. Liu WM, Powles T, Shamash J, Propper D, Oliver T, Joel S. Effect of haemopoietic growth factors on cancer cell lines and their role in chemosensitivity. Oncogene. 2004;23(4):981-990.

261. Mitjavila MT, Villeval JL, Cramer P, et al. Effects of granulocytemacrophage colony-stimulating factor and erythropoietin on leukemic erythroid colony formation in human early erythroblastic leukemias. Blood. 1987;70(4):965-973.

262. Asano Y, Okamura S, Shibuya T, Harada M, Niho Y. Growth of clonogenic myeloblastic leukemic cells in the presence of human recombinant erythropoietin in addition to various human recombinant hematopoietic growth factors. Blood. 1988;72(5):1682-1686.

263. Kolonics A, Apati A, Nahajevszky S, Gati R, Brozik A, Magocsi M. Unregulated activation of STAT-5, ERK1/2 and c-Fos may contribute to the phenotypic transformation from myelodysplastic syndrome to acute leukaemia. Haematologia. 2001;31(2):125-138.

264. Ohigashi T, Yoshioka K, Fisher JW. Autocrine regulation of erythropoietin gene expression in human hepatocellular carcinoma cells. Life Sci. 1996;58(5):421-427.

265. Westenfelder C, Baranowski RL. Erythropoietin stimulates proliferation of human renal carcinoma cells. Kidney Int. 2000;58(2): 647-657.

266. Kitamura T, Tojo A, Kuwaki T, et al. Identification and analysis of human erythropoietin receptors on a factor-dependent cell line, TF-1. Blood. 1989;73(2):375-380.

267. Nakazawa M, Mitjavila MT, Debili N, et al. KU 812: a pluripotent human cell line with spontaneous erythroid terminal maturation. Blood. 1989;73(7):2003-2013.

268. van Zoelen EJ. Receptor-ligand interaction: a new method for determining binding parameters without a priori assumptions on non-specific binding. Biochem J. 1989;262(2):549-556.

269. Pelletier S, Gingras S, Funakoshi-Tago M, Howell S, Ihle JN. Two domains of the erythropoietin receptor are sufficient for Jak2 binding/activation and function. Mol Cell Biol. 2006;26(22): 8527-8538.

270. Shannon AM, Bouchier-Hayes DJ, Condron CM, Toomey D. Correction of anaemia through the use of darbepoetin alfa improves chemotherapeutic outcome in a murine model of Lewis lung carcinoma. Br J Cancer. 2005;93(2):224-232.

271. Fu P, Jiang X, Arcasoy MO. Constitutively active erythropoietin receptor expression in breast cancer cells promotes cellular proliferation and migration through a MAP-kinase dependent pathway. Biochem Biophys Res Commun. 2009;379(3):696-701.

272. Hardee ME, Cao Y, Fu P, et al. Erythropoietin blockade inhibits the induction of tumor angiogenesis and progression. PloS One 2007;(6):e549.

273. Dunlop EA, Percy MJ, Boland MP, Maxwell AP, Lappin TR. Induction of signalling in non-erythroid cells by pharmacological levels of erythropoietin. Neurodegener Dis. 2006;3(1-2):94-100. 
274. Um M, Lodish HF. Antiapoptotic effects of erythropoietin in differentiated neuroblastoma SH-SY5Y cells require activation of both the STAT5 and AKT signaling pathways. J Biol Chem. 2006; 281(9):5648-5656.

275. Liang K, Esteva FJ, Albarracin C, et al. Recombinant human erythropoietin antagonizes trastuzumab treatment of breast cancer cells via Jak2-mediated Src activation and PTEN inactivation. Cancer Cell. 2010;18(5):423-435.

276. Mirmohammadsadegh A, Marini A, Gustrau A, et al. Role of erythropoietin receptor expression in malignant melanoma. J Invest Dermatol. 2010;130(1):201-210.

277. Arcasoy MO, Amin K, Karayal AF, et al. Functional significance of erythropoietin receptor expression in breast cancer. Lab Invest. 2002;82(7):911-918.

278. Hamadmad SN, Hohl RJ. Erythropoietin stimulates cancer cell migration and activates RhoA protein through a mitogen-activated protein kinase/extracellular signal-regulated kinase-dependent mechanism. J Pharmacol Exp Ther. 2008;324(3):1227-1233.

279. Sinclair A, Archibeque I, Zhan J, et al. Janus kinase (JAK) 2 potency and selectivity assessment of small molecules: widely used AG490 inhibitor is neither potent nor selective for JAK2. Blood. 2011;118(21):4780

280. Kirken RA, Erwin RA, Taub D, et al. Tyrphostin AG-490 inhibits cytokine-mediated JAK3/STAT5a/b signal transduction and cellular proliferation of antigen-activated human T cells. J Leuke Biol. 1999;65(6):891-899.

281. Gazit A, Osherov N, Posner I, et al. Tyrphostins. 2. Heterocyclic and alpha-substituted benzylidenemalononitrile tyrphostins as potent inhibitors of EGF receptor and ErbB2/neu tyrosine kinases. $J$ Med Chem. 1991;34(6):1896-1907.

282. Jaleel M, Shenoy AR, Visweswariah SS. Tyrphostins are inhibitors of guanylyl and adenylyl cyclases. Biochem. 2004;43(25): $8247-8255$.

283. Kaur G, Gazit A, Levitzki A, Stowe E, Cooney DA, Sausville EA. Tyrphostin induced growth inhibition: correlation with effect on p210bcr-abl autokinase activity in K562 chronic myelogenous leukemia. Anticancer Drugs. 1994;5(2):213-222.

284. Gewirtz DA, Di X, Walker TD, Sawyer ST. Erythropoietin fails to interfere with the antiproliferative and cytotoxic effects of antitumor drugs. Clin Cancer Res. 2006;12(7 Pt 1):2232-2238.

285. Fandrey J, Dicato M. Examining the involvement of erythropoiesisstimulating agents in tumor proliferation (erythropoietin receptors, receptor binding, signal transduction), angiogenesis, and venous thromboembolic events. Oncologist. 2009;14 Suppl 1:34-42.

286. Ammarguellat F, Llovera M, Kelly PA, Goffin V. Low doses of EPO activate MAP kinases but not JAK2-STAT5 in rat vascular smooth muscle cells. Biochem Biophys Res Commun. 2001;284(4): 1031-1038

287. Hardee ME, Cao Y, Fu P, et al. Erythropoietin blockade inhibits the induction of tumor angiogenesis and progression. PloS One. 2007;(6):e549.

288. Lester RD, Jo M, Campana WM, Gonias SL. Erythropoietin promotes MCF-7 breast cancer cell migration by an ERK/mitogen-activated protein kinase-dependent pathway and is primarily responsible for the increase in migration observed in hypoxia. $J$ Biol Chem. 2005;280(47):39273-39277.

289. Seidel HM, Lamb P, Rosen J. Pharmaceutical intervention in the JAK/ STAT signaling pathway. Oncogene. 2000;19(21):2645-2656.

290. Jatiani SS, Baker SJ, Silverman LR, Premkumar RE. JAK/STAT pathways in cytokine signaling and myeloproliferative disorders: approaches for targeted therapies. Genes Cancer. 2010;1(10):979-993.

291. Parganas E, Wang D, Stravopodis D, et al. Jak2 is essential for signaling through a variety of cytokine receptors. Cell. 1998;93(3): 385-395.

292. Swift S, Elliott S, Sinclair A, Begley CG. Erythropoietin receptor in ovarian cancer cells - Letter. Mol Cancer Ther. 2010;9(4): 1070-1071.
293. Hsu RY, Chan CH, Spicer JD, et al. LPS-induced TLR4 signaling in human colorectal cancer cells increases beta1 integrin-mediated cell adhesion and liver metastasis. Cancer Res. 2011;71(5): 1989-1998.

294. Doan HQ, Bowen KA, Jackson LA, Evers BM. Toll-like receptor 4 activation increases Akt phosphorylation in colon cancer cells. Anticancer Res. 2009;29(7):2473-2478.

295. Keenan J, Dooley M, Pearson D, Clynes M. Recombinant human albumin in cell culture: evaluation of growth-promoting potential for NRK and SCC-9 cells in vitro. Cytotechnology. 1996;24(243):252.

296. Slaaby R, Andersen AS, Brandt J. IGF-I binding to the IGF-I receptor is affected by contaminants in commercial BSA: the contaminants are proteins with IGF-I binding properties. Growth Horm IGF Res. 2008;18(4):267-274.

297. Etherton TD, Chung CS, Wiggins JP. Receptor-dependent and independent degradation of insulin by isolated swine adipocytes at $37 \mathrm{C}$. J Anim Sci. 1984;59(2):366-375.

298. Blair KJ, Kiang A, Wang-Rodriguez J, Yu MA, Doherty JK, Ongkeko WM. EGF and bFGF promote invasion that is modulated by PI3/ Akt kinase and Erk in vestibular schwannoma. Otol Neurotol. 2011;32(2):308-314.

299. Hassouna I, Sperling S, Kim E, et al. Erythropoietin augments survival of glioma cells after radiation and temozolomide. Int J Radiat Oncol Biol Phys. 2008;72(3):927-934.

300. LaMontagne KR, Butler J, Marshall DJ, et al. Recombinant epoetins do not stimulate tumor growth in erythropoietin receptor-positive breast carcinoma models. Mol Cancer Ther. 2006;5(2):347-355.

301. Quesenberry P, Levin J, Zuckerman K, Rencricca N, Sullivan R, Tyler W. Stem cell migration induced by erythropoietin or haemolytic anaemia: the effects of actinomycin and endotoxin contamination of erythropoietin preparations. Br J Haematol. 1979;41(2): 253-269.

302. Harmey JH, Bucana CD, Lu W, et al. Lipopolysaccharideinduced metastatic growth is associated with increased angiogenesis, vascular permeability and tumor cell invasion. Int $J$ Cancer. 2002;101(5):415-422.

303. Killeen SD, Wang JH, Andrews EJ, Redmond HP. Bacterial endotoxin enhances colorectal cancer cell adhesion and invasion through TLR-4 and NF-kappaB-dependent activation of the urokinase plasminogen activator system. Br J Cancer. 2009;100(10):1589-1602.

304. Wang JH, Manning BJ, Wu QD, Blankson S, Bouchier-Hayes D, Redmond HP. Endotoxin/lipopolysaccharide activates NF-kappa $\mathrm{B}$ and enhances tumor cell adhesion and invasion through a beta 1 integrin-dependent mechanism. J Immunol. 2003;170(2): 795-804.

305. Sugawa M, Fukui H. Effects of recombinant human erythropoietin on the growth of various human tumor cells. Biotherapy. 2005; 19(2):181-196.

306. Bauer E, Danhauser-Riedl S, De RW, et al. Effects of recombinant human erythropoietin on clonogenic growth of primary human tumour specimens in vitro. Eur J Cancer. 1992;28A(10):1769.

307. Miller CP, Valliant-Saunders K, Blau CA. Limitations of a murine transgenic breast cancer model for studies of erythropoietin-induced tumor progression. Clin Transl Oncol. 2010;3(3):176-180.

308. Yasuda Y, Musha T, Tanaka H, et al. Inhibition of erythropoietin signalling destroys xenografts of ovarian and uterine cancers in nude mice. Br J Cancer. 2001;84(6):836-843.

309. Yarkoni E, Goren MB, Rapp HJ. Regression of a transplanted guinea pig hepatoma after intralesional injection of an emulsified mixture of endotoxin and mycobacterial sulfolipid. Infect Immun. 1979; 24(2):357-362.

310. Villeval JL, Mitjavila MT, Dusanter-Fourt I, Wendling F, Mayeux P, Vainchenker W. Autocrine stimulation by erythropoietin (Epo) requires Epo secretion. Blood. 1994;84(8):2649-2662.

311. Rasko JE, Metcalf D, Gough NM, Begley CG. The cytokine receptor repertoire specifies autocrine growth factor production in factordependent cells. Exp Hematol. 1995;23(5):453-460. 
312. Palumbo C, Battisti S, Carbone D, et al. Recombinant erythropoietin differently affects proliferation of mesothelioma cells but not sensitivity to cisplatin and pemetrexed. Cancer Chemother Pharmacol. 2008;61(5):893-901.

313. Acs G, Chen M, Xu X, Acs P, Verma A, Koch CJ. Autocrine erythropoietin signaling inhibits hypoxia-induced apoptosis in human breast carcinoma cells. Cancer Lett. 2004;214(2):243-251.

314. Kumar SM, Acs G, Fang D, Herlyn M, Elder DE, Xu X. Functional erythropoietin autocrine loop in melanoma. Am J Pathol. 2005;166(3): 823-830.

315. Hankins WD, Schooley J, Eastment C. Erythropoietin, an autocrine regulator? Serum-free production of erythropoietin by cloned erythroid cell lines. Blood. 1986;68(1):263-268.

316. Qian RL, Chin K, Kim JK, Chin HM, Cone J, Hankins WD. Purification of murine erythropoietin produced in serum-free cultures of erythroleukemia cells. Blood. 1986;68(1):258-262.

317. Mitjavila MT, Le Couedic JP, Casadevall N. Autocrine stimulation by erythropoietin and autonomous growth of human erythroid leukemic cells in vitro. J Clin lnvest. 1991;88(3):789-797.

318. Sherwood JB, Shouval D. Continuous production of erythropoietin by an established human renal carcinoma cell line: development of the cell line. Proc Natl Acad Sci U S A. 1986;83(1):165-169.

319. Shouval D, Sherwood JB. Production of erythropoietin by an established human renal carcinoma cell line: in vitro and in vivo studies. Adv Exp Med Biol. 1988;241:319-328.

320. Hammond D, Winnick S. Paraneoplastic erythrocytosis and ectopic erythropoietins. Ann N Y Acad Sci. 1974;230:219-227.

321. Kaelin WG Jr. The von Hippel-Lindau tumour suppressor protein: $\mathrm{O}_{2}$ sensing and cancer. Nat Rev Cancer. 2008;8(11):865-873.

322. Berdel WE, Danhauser-Riedl S, Oberberg D, Zafferani M. Effects of hematopoietic growth factors on malignant nonhematopoietic cells. Semin Oncol. 1992;19(2 Suppl 4):41-45.

323. Hamamori Y, Samal B, Tian J, Kedes L. Persistent erythropoiesis by myoblast transfer of erythropoietin cDNA. Hum Gene Ther. 1994;5(11):1349-1356.

324. Muramatsu T, Arakawa S, Fukazawa K, et al. In vivo gene electroporation in skeletal muscle with special reference to the duration of gene expression. Int J Mol Med. 2001;7(1):37-42.

325. Geudens I, Gerhardt H. Coordinating cell behaviour during blood vessel formation. Development. 2011;138(21):4569-4583.

326. Wu H, Lee SH, Gao J, Liu X, Iruela-Arispe ML. Inactivation of erythropoietin leads to defects in cardiac morphogenesis. Development. 1999;126(16):3597-3605.

327. Kertesz N, Wu J, Chen TH, Sucov HM, Wu H. The role of erythropoietin in regulating angiogenesis. Dev Biol. 2004;276(1):101-110.

328. Davidoff AM, Ng CY, Brown P, et al. Bone marrow-derived cells contribute to tumor neovasculature and, when modified to express an angiogenesis inhibitor, can restrict tumor growth in mice. Clin Cancer Res. 2001;7(9):2870-2879.

329. DePalma M, Naldini L. Role of haematopoietic cells and endothelial progenitors in tumour angiogenesis. Biochim Biophys Acta. 2006;1766(1):159-166.

330. Zwezdaryk KJ, Coffelt SB, Figueroa YG, et al. Erythropoietin, a hypoxia-regulated factor, elicits a pro-angiogenic program in human mesenchymal stem cells. Exp Hematol. 2007;35(4):640-652; [Erratum, Exp Hematol. 2007;35(7):1153-1161].

331. Hao Q, Liu JR, Pappu R, et al. Contribution of bone marrowderived cells associated with brain angiogenesis is primarily through leukocytes and macrophages. Arterioscler Thromb Vasc Biol. 2008; 28(12):2151-2157.

332. Muller-Ehmsen J, Schmidt A, Krausgrill B, Schwinger RH, Bloch W. Role of erythropoietin for angiogenesis and vasculogenesis: from embryonic development through adulthood. Am J Physiol Heart Circ Physiol. 2006;290(1):H331-H340.

333. Perry TE, Song M, Despres DJ, et al. Bone marrow-derived cells do not repair endothelium in a mouse model of chronic endothelial cell dysfunction. Cardiovasc Res. 2009;84(2):317-325.
334. Scherschel JA, Soonpaa MH, Srour EF, Field LJ, Rubart M. Adult bone marrow-derived cells do not acquire functional attributes of cardiomyocytes when transplanted into peri-infarct myocardium. $\mathrm{Mol}$ Ther. 2008;16(6):1129-1137.

335. Gothert JR, Gustin SE, van Eekelen JA, et al. Genetically tagging endothelial cells in vivo: bone marrow-derived cells do not contribute to tumor endothelium. Blood. 2004;104(6):1769-1777.

336. Ziegelhoeffer T, Fernandez B, Kostin S, et al. Bone marrow-derived cells do not incorporate into the adult growing vasculature. Circ Res. 2004;94(2):230-238.

337. Crivellato E, Nico B, Vacca A, Djonov V, Presta M, Ribatti D. Recombinant human erythropoietin induces intussusceptive microvascular growth in vivo. Leukemia. 2004;18(2):331-336.

338. Jaquet K, Krause K, Tawakol-Khodai M, Geidel S, Kuck KH. Erythropoietin and VEGF exhibit equal angiogenic potential. Microvasc Res. 2002;64(2):326-333.

339. Bahlmann FH, DeGroot K, Duckert T, et al. Endothelial progenitor cell proliferation and differentiation is regulated by erythropoietin. Kidney Int. 2003;64(5):1648-1652.

340. Bahlmann FH, Song R, Boehm SM, et al. Low-dose therapy with the long-acting erythropoietin analogue darbepoetin alpha persistently activates endothelial Akt and attenuates progressive organ failure. Circulation. 2004;110(8):1006-1012.

341. Heeschen C, Aicher A, Lehmann R, et al. Erythropoietin is a potent physiologic stimulus for endothelial progenitor cell mobilization. Blood. 2003;102(4):1340-1346.

342. Perrotta S, Cucciolla V, Ferraro M, et al. EPO receptor gain-of-function causes hereditary polycythemia, alters CD34 cell differentiation and increases circulating endothelial precursors. PloS One. 2010; $5(8): 2010$.

343. Duff SE, Li C, Garland JM, Kumar S. CD105 is important for angiogenesis: evidence and potential applications. FASEB J. 2003;17(9):984-992.

344. Buhring HJ, Muller CA, Letarte M, et al. Endoglin is expressed on a subpopulation of immature erythroid cells of normal human bone marrow. Leukemia. 1991;5(10):841-847.

345. Kim SN, Moon JH, Kim JG, et al. Mobilization effects of G-CSF, GM-CSF, and darbepoetin-alpha for allogeneic peripheral blood stem cell transplantation. J Clin Apher. 2009;24(5):173-179.

346. Taniguchi N, Sawada T, Matsubara K, et al. Erythropoietin prevention trial of coronary restenosis and cardiac remodeling after ST-elevated acute myocardial infarction (EPOC-AMI): a pilot, randomized, placebo-controlled study. Circ J. 2010;74(11):2365-2371.

347. Pawlak K, Pawlak D, Mysliwiec M. Long-term erythropoietin therapy does not affect endothelial markers, coagulation activation and oxidative stress in haemodialyzed patients. Thromb Res. 2007;120(6):797-803.

348. Tsuzuki M. Bone marrow-derived cells are not involved in reendothelialized endothelium as endothelial cells after simple endothelial denudation in mice. Basic Res Cardiol. 2009;104(5):601-611.

349. Peters BA, Diaz LA, Polyak K, et al. Contribution of bone marrowderived endothelial cells to human tumor vasculature. Nat Med. 2005;11(3):261-262.

350. Machein MR, Renninger S, de Lima-Hahn E, Plate KH. Minor contribution of bone marrow-derived endothelial progenitors to the vascularization of murine gliomas. Brain Pathol. 2003;13(4): 582-597.

351. Suzuki N, Ohneda O, Takahashi S, et al. Erythroid-specific expression of the erythropoietin receptor rescued its null mutant mice from lethality. Blood. 2002;100(7):2279-2288.

352. Ammarguellat F, Gogusev J, Drueke TB. Direct effect of erythropoietin on rat vascular smooth-muscle cell via a putative erythropoietin receptor. Nephrol Dial Transplant. 1996;11(4):687-692.

353. Lopez Ongil SL, Saura M, Lamas S, Rodriguez PM, Rodriguez PD. Recombinant human erythropoietin does not regulate the expression of endothelin-1 and constitutive nitric oxide synthase in vascular endothelial cells. Exp Nephrol. 1996;4(1):37-42. 
354. Fuste B, az-Ricart M, Cases A, Lopez-Pedret J, Ordinas A, Escolar G. Erythropoietin does not modify the prothrombotic effect induced by uremic media on endothelial cells. Haematologica. 2002;87(9): 1006-1008.

355. Hardee ME, Kirkpatrick JP, Shan S, et al. Human recombinant erythropoietin (rEpo) has no effect on tumour growth or angiogenesis. Br J Cancer. 2005;93(12):1350-1355.

356. Sairah AK, Rasedee A, Sheikh O, Rozita R, ALHaj N. The effects of recombinant human erythropoietin and tamoxifen on growth and angiogenesis of mammary tumor in Sprague-Dawley rat. Am J Pharmacol Toxicol. 2009;4(1):12-16.

357. Pinel S, Barberi-Heyob M, Cohen-Jonathan E, et al. Erythropoietininduced reduction of hypoxia before and during fractionated irradiation contributes to improvement of radioresponse in human glioma xenografts. Int J Radiat Oncol Biol Phys. 2004;59(1): 250-259.

358. Yamaji R, Okada T, Moriya M, et al. Brain capillary endothelial cells express two forms of erythropoietin receptor mRNA. Eur J Biochem. 1996;239(2):494-500.

359. Anagnostou A, Lee ES, Kessimian N, Levinson R, Steiner M. Erythropoietin has a mitogenic and positive chemotactic effect on endothelial cells. Proc Natl Acad Sci U S A. 1990;87(15): 5978-5982.

360. Ribatti D, Presta M, Vacca A, et al. Human erythropoietin induces a pro-angiogenic phenotype in cultured endothelial cells and stimulates neovascularization in vivo. Blood. 1999;93(8):2627-2636.

361. Nico B, Annese T, Guidolin D, Finato N, Crivellato E, Ribatti D. Epo is involved in angiogenesis in human glioma. $J$ Neurooncol. 2011;102(1):51-58.

362. Samarut J, Nigon V. In vitro development of chicken erythropoietinsensitive cells. Exp Cell Res. 1976;100(2):245-248.

363. Steinlein P, Deiner E, Leutz A, Beug H. Recombinant murine erythropoietin receptor expressed in avian erythroid progenitors mediates terminal erythroid differentiation in vitro. Growth Factors. 1994;10(1):1-16.

364. Koo BC, Kwon MS, Lee H, et al. Tetracycline-dependent expression of the human erythropoietin gene in transgenic chickens. Transgenic Res. 2010;19(3):437-447.

365. Yu X, Shacka JJ, Eells JB, et al. Erythropoietin receptor signalling is required for normal brain development. Development. 2002; 129(2):505-516.

366. Satoh K, Kagaya Y, Nakano M, et al. Important role of endogenous erythropoietin system in recruitment of endothelial progenitor cells in hypoxia-induced pulmonary hypertension in mice. Circulation. 2006;113(11):1442-1450.

367. Nakano M, Satoh K, Fukumoto Y, et al. Important role of erythropoietin receptor to promote VEGF expression and angiogenesis in peripheral ischemia in mice. Circ Res. 2007;100(5):662-669.

368. Calvillo L, Latini R, Kajstura J, et al. Recombinant human erythropoietin protects the myocardium from ischemia-reperfusion injury and promotes beneficial remodeling. Proc Natl Acad Sci U SA. 2003;100(8):4802-4806.

369. Moon C, Krawczyk M, Ahn D, et al. Erythropoietin reduces myocardial infarction and left ventricular functional decline after coronary artery ligation in rats. Proc Natl Acad Sci U S A. 2003;100(20): 11612-11617.

370. Tramontano AF, Muniyappa R, Black AD, et al. Erythropoietin protects cardiac myocytes from hypoxia-induced apoptosis through an Akt-dependent pathway. Biochem Biophys Res Commun. 2003; 308(4):990-994.

371. Baker JE, Kozik D, Hsu AK, Fu X, Tweddell JS, Gross GJ. Darbepoetin alfa protects the rat heart against infarction: dose-response, phase of action, and mechanisms. J Cardiovasc Pharmacol. 2007; 49(6):337-345.

372. Parsa CJ, Kim J, Riel RU, et al. Cardioprotective effects of erythropoietin in the reperfused ischemic heart: a potential role for cardiac fibroblasts. J Biol Chem. 2004;279(20):20655-20662.
373. Asaumi Y, Kagaya Y, Takeda M, et al. Protective role of endogenous erythropoietin system in nonhematopoietic cells against pressure overload-induced left ventricular dysfunction in mice. Circulation. 2007;115(15):2022-2032.

374. Tada H, Kagaya Y, Takeda M, et al. Endogenous erythropoietin system in non-hematopoietic lineage cells plays a protective role in myocardial ischemia/reperfusion. Cardiovasc Res. 2006;71(3):466-477.

375. Siren AL, Fratelli M, Brines M, et al. Erythropoietin prevents neuronal apoptosis after cerebral ischemia and metabolic stress. Proc Natl Acad Sci U S A. 2001;98(7):4044-4049.

376. Sakanaka M, Wen TC, Matsuda S, et al. In vivo evidence that erythropoietin protects neurons from ischemic damage. Proc Natl Acad Sci U S A. 1998;95(8):4635-4640.

377. Gorio A, Gokmen N, Erbayraktar S, et al. Recombinant human erythropoietin counteracts secondary injury and markedly enhances neurological recovery from experimental spinal cord trauma. Proc Natl Acad Sci U SA. 2002;99(14):9450-9455.

378. Salahudeen AK, Haider N, Jenkins J, et al. Antiapoptotic properties of erythropoiesis-stimulating proteins in models of cisplatin-induced acute kidney injury. Am J Physiol Renal Physiol. 2008;294(6):F1354-F1365.

379. Bahlmann FH, Fliser D. Erythropoietin and renoprotection. Curr Opin Nephrol Hypertens. 2009;18(1):15-20.

380. Lombardero M, Kovacs K, Scheithauer BW. Erythropoietin: a hormone with multiple functions [review]. Pathobiology. 2011;78(1):41-53.

381. Arcasoy MO. The non-haematopoietic biological effects of erythropoietin. Br J Haematol. 2008;141(1):14-31.

382. Minh KL, Klemm K, Abshagen K, Eipel C, Menger MD, Vollmar B. Attenuation of inflammation and apoptosis by pre- and posttreatment of darbepoetin-alpha in acute liver failure of mice. Am J Pathol. 2007;170(6): 1954-1963.

383. Sepodes B, Maio R, Pinto R, et al. Recombinant human erythropoietin protects the liver from hepatic ischemia-reperfusion injury in the rat. Transpl Int. 2006;19(11):919-926.

384. Katavetin P, Tungsanga K, Eiam-Ong S, Nangaku M. Antioxidative effects of erythropoietin. Kidney Int. 2007;72 Suppl 107:S10-S15.

385. Marti HH, Gassmann M, Wenger RH, et al. Detection of erythropoietin in human liquor: intrinsic erythropoietin production in the brain. Kidney Int. 1997;51(2):416-418.

386. Banks WA, Jumbe NL, Farrell CL, Niehoff ML, Heatherington AC. Passage of erythropoietic agents across the blood-brain barrier: a comparison of human and murine erythropoietin and the analog darbepoetin alfa. Eur J Pharmacol. 2004;505(1-3):93-101.

387. Juul SE, Harcum J, Li Y, Christensen RD. Erythropoietin is present in the cerebrospinal fluid of neonates. J Pediatr. 1997;130(3):428-430.

388. Tsai PT, Ohab JJ, Kertesz N, et al. A critical role of erythropoietin receptor in neurogenesis and post-stroke recovery. J Neurosci. 2006; 26(4):1269-1274.

389. Chen X, Chen Y, Bi Y, et al. Preventive cardioprotection of erythropoietin against doxorubicin-induced cardiomyopathy. Cardiovasc Drugs Ther. 2007;21(5):367-374.

390. Juul SE, Yachnis AT, Christensen RD. Tissue distribution of erythropoietin and erythropoietin receptor in the developing human fetus. Early Hum Dev. 1998;52(3):235-249.

391. Westenfelder C, Biddle DL, Baranowski RL. Human, rat, and mouse kidney cells express functional erythropoietin receptors. Kidney Int. 1999;55(3):808-820.

392. Cai Z, Manalo DJ, Wei G, et al. Hearts from rodents exposed to intermittent hypoxia or erythropoietin are protected against ischemiareperfusion injury. Circulation. 2003;108(1):79-85.

393. Brines M, Grasso G, Fiordaliso F, et al. Erythropoietin mediates tissue protection through an erythropoietin and common betasubunit heteroreceptor. Proc Natl Acad Sci U S A. 2004;101(41): 14907-14912.

394. Agarwal N, Gordeuk VR, Prchal JT. Are erythropoietin receptors expressed in tumors? Facts and fiction - more careful studies are needed. J Clin Oncol. 2007;25(13):1813-1814. 
395. Parsa CJ, Matsumoto A, Kim J, et al. A novel protective effect of erythropoietin in the infarcted heart. J Clin Invest. 2003;112(7): 999-1007.

396. Akimoto T, Kusano E, Inaba T, et al. Erythropoietin regulates vascular smooth muscle cell apoptosis by a phosphatidylinositol 3 kinasedependent pathway. Kidney Int. 2000;58(1):269-282.

397. Fiordaliso F, Chimenti S, Staszewsky L, et al. A nonerythropoietic derivative of erythropoietin protects the myocardium from ischemia-reperfusion injury. Proc Natl Acad Sci U S A. 2005;102(6): 2046-2051.

398. Zhang D, Zhang F, Zhang Y, et al. Erythropoietin enhances the angiogenic potency of autologous bone marrow stromal cells in a rat model of myocardial infarction. Cardiology. 2007;108(4): 228-236.

399. Ruscher K, Freyer D, Karsch M, et al. Erythropoietin is a paracrine mediator of ischemic tolerance in the brain: evidence from an in vitro model. J Neurosci. 2002;22(23):10291-10301.

400. Yang CW, Li C, Jung JY, et al. Preconditioning with erythropoietin protects against subsequent ischemia-reperfusion injury in rat kidney. FASEB J. 2003;17(12):1754-1755.

401. Vesey DA, Cheung C, Pat B, Endre Z, Gobe G, Johnson DW. Erythropoietin protects against ischaemic acute renal injury. Nephrol Dial Transplant. 2004;19(2):348-355.

402. Nemoto T, Yokota N, Keane WF, Rabb H. Recombinant erythropoietin rapidly treats anemia in ischemic acute renal failure. Kidney Int. 2001; 59(1):246-251.

403. Koh SH, Kim Y, Kim HY, Cho GW, Kim KS, Kim SH. Recombinant human erythropoietin suppresses symptom onset and progression of G93A-SOD1 mouse model of ALS by preventing motor neuron death and inflammation. Eur J Neurosci. 2007;25(7): 1923-1930.

404. Grunfeld JF, Barhum Y, Blondheim N, Rabey JM, Melamed E, Offen D. Erythropoietin delays disease onset in an amyotrophic lateral sclerosis model. Exp Neurol. 2007;204(1):260-263.

405. Grignaschi G, Zennaro E, Tortarolo M, Calvaresi N, Bendotti C. Erythropoietin does not preserve motor neurons in a mouse model of familial ALS. Amyotroph Lateral Scler. 2007;8(1):31-35.

406. Agnello D, Bigini P, Villa P, et al. Erythropoietin exerts an antiinflammatory effect on the CNS in a model of experimental autoimmune encephalomyelitis. Brain Res. 2002;952(1):128-134.

407. Brendt P, Frey U, Adamzik M, Schafer ST, Peters J. Darbepoetin alpha, a long-acting erythropoeitin derivate, does not alter LPS evoked myocardial depression and gene expression of Bax, Bcl-Xs, Bcl-XL, Bcl-2, and TNF-alpha. Shock. 2009;31(1): 50-54.

408. Spreer A, Gerber J, Hanssen M, Nau R. No neuroprotective effect of erythropoietin under clinical treatment conditions in a rabbit model of Escherichia coli meningitis. Pediatr Res. 2007;62(6): 680-683

409. Sølling C. Organ-protective and immunomodulatory effects of erythropoietin - an update on recent clinical trials. Basic Clin Pharmacol Toxicol. 2012;110(2):113-121.

410. Ehrenreich H, Weissenborn K, Prange H, et al. Recombinant human erythropoietin in the treatment of acute ischemic stroke. Stroke. 2009;40(12):e647-e656.

411. Springborg JB, Moller C, Gideon P, Jorgensen OS, Juhler M, Olsen NV. Erythropoietin in patients with aneurysmal subarachnoid haemorrhage: a double blind randomised clinical trial. Acta Neurochir (Wien). 2007;149(11):1089-1100.

412. Talving P, Lustenberger T, Kobayashi L, et al. Erythropoiesis stimulating agent administration improves survival after severe traumatic brain injury: a matched case control study. Ann Surg. 2010; 251(1): $1-4$.

413. Binbrek AS, Rao NS, Al KN, Assaqqaf J, Sobel BE. Erythropoietin to augment myocardial salvage induced by coronary thrombolysis in patients with ST segment elevation acute myocardial infarction. Am J Cardiol. 2009;(8):1035-1040.
414. Cleland JG, Coletta AP, Clark AL, Cullington D. Clinical trials update from the American College of Cardiology 2009: ADMIRE-HF, PRIMA, STICH, REVERSE, IRIS, partial ventricular support, FIXHF-5, vagal stimulation, REVIVAL-3, pre-RELAX-AHF, ACTIVE-A, HF-ACTION, JUPITER, AURORA, and OMEGA. Eur J Heart Fail. 2009;11(6):622-630.

415. Ferrario M, Arbustini E, Massa M, et al. High-dose erythropoietin in patients with acute myocardial infarction: a pilot, randomised, placebocontrolled study. Int J Cardiol. 2011;147(1):124-131.

416. Najjar SS, Rao SV, Melloni C, et al. Intravenous erythropoietin in patients with ST-segment elevation myocardial infarction: REVEAL: a randomized controlled trial. JAMA. 2011;305(18):1863-1872.

417. Ott I, Schulz S, Mehilli J, et al. Erythropoietin in patients with acute st-segment elevation myocardial infarction undergoing primary percutaneous coronary intervention a randomized, double-blind trial. Circ Cardiovasc Interv. 2010;3(5):408-413.

418. Rao SV, Kilaru R, Povsic TJ, et al. A randomized placebo controlled trial of intravenous erythropoietin to reduce infarct size after st-segment elevation myocardial infarction: primary results of the REVEAL trial. Circulation. 2010;122(21):2222.

419. Voors AA, Belonje AM, Zijlstra F, et al. A single dose of erythropoietin in ST-elevation myocardial infarction. Eur Heart J. 2010;31(21): 2593-2600.

420. Becker BN, Becker YT, Leverson GE, Heisey DM. Erythropoietin therapy may retard progression in chronic renal transplant dysfunction. Nephrol Dial Transplant. 2002;17(9):1667-1673.

421. Hafer C, Becker T, Kielstein JT, et al. High-dose erythropoietin has no effect on short-or long-term graft function following deceased donor kidney transplantation. Kidney Int. 2012;81(3):314-320.

422. Kamar N, Reboux A-H, Cointault O, et al. Impact of very early high doses of recombinant erythropoietin on anemia and allograft function in de novo kidney-transplant patients. Transpl Int. 2010;23(3): 277-284.

423. Martinez F, Kamar N, Pallet N, et al. High dose epoetin beta in the first weeks following renal transplantation and delayed graft function: results of the Neo-PDGF study [brief communication]. Am J Transplant. 2010;10(7):1704-1709.

424. Endre ZH, Walker RJ, Pickering JW, et al. Early intervention with erythropoietin does not affect the outcome of acute kidney injury (the EARLYARF trial). Kidney Int. 2010;77(11):1020-1030.

425. Park J, Gage BF, Vijayan A. Use of EPO in critically ill patients with acute renal failure requiring renal replacement therapy. American Journal of Kidney Diseases 2005;46(5):791-798.

426. Song YR, Lee T, You SJ, et al. Prevention of acute kidney injury by erythropoietin in patients undergoing coronary artery bypass grafting: a pilot study. Am J Nephrol. 2009;30(3):253-260.

427. Christensen B, Lundby C, Jessen N, et al. Evaluation of functional erythropoietin receptor status in skeletal muscle in vivo: acute and prolonged studies in healthy human subjects. PloS One 2012;7(2):e31857.

428. Leist M, Ghezzi P, Grasso G, et al. Derivatives of erythropoietin that are tissue protective but not erythropoietic. Science. 2004; 305(5681):239-242.

429. Moon C, Krawczyk M, Paik D, et al. Erythropoietin, modified to not stimulate red blood cell production, retains its cardioprotective properties. J Pharmacol Exp Ther. 2006;316(3):999-1005.

430. Imamura R, Isaka Y, Ichimaru N, Takahara S, Okuyama A. Carbamylated erythropoietin protects the kidneys from ischemia-reperfusion injury without stimulating erythropoiesis. Biochem Biophys Res Commun. 2007;353(3):786-792.

431. Imamura R, Okumi M, Isaka Y, et al. Carbamylated erythropoietin improves angiogenesis and protects the kidneys from ischemia-reperfusion injury. Cell Transplant. 2008;17(1-2):135-141.

432. Kitamura H, Isaka Y, Takabatake Y, et al. Nonerythropoietic derivative of erythropoietin protects against tubulointerstitial injury in a unilateral ureteral obstruction model. Nephrol Dial Transplant. 2008;23(5):1521-1528. 
433. King VR, Averill SA, Hewazy D, Priestley JV, Torup L, Michael-Titus AT. Erythropoietin and carbamylated erythropoietin are neuroprotective following spinal cord hemisection in the rat. Eur J Neurosci. 2007;26(1):90-100.

434. Montero M, Poulsen FR, Noraberg J, et al. Comparison of neuroprotective effects of erythropoietin (EPO) and carbamylerythropoietin (CEPO) against ischemia-like oxygen-glucose deprivation (OGD) and NMDA excitotoxicity in mouse hippocampal slice cultures. Exp Neurol. 2007;204(1):106-117.

435. Schmidt RE, Green KG, Feng D, et al. Erythropoietin and its carbamylated derivative prevent the development of experimental diabetic autonomic neuropathy in STZ-induced diabetic NOD-SCID mice. Exp Neurol. 2008;209(1):161-170.

436. Robb L, Drinkwater CC, Metcalf D, et al. Hematopoietic and lung abnormalities in mice with a null mutation of the common beta subunit of the receptors for granulocyte-macrophage colony-stimulating factor and interleukins 3 and 5. Proc Natl Acad Sci U S A. 1995;92(21): 9565-9569.

437. Nicola NA, Robb L, Metcalf D, Cary D, Drinkwater CC, Begley CG. Functional inactivation in mice of the gene for the interleukin-3 (IL3)-specific receptor beta-chain: implications for IL-3 function and the mechanism of receptor transmodulation in hematopoietic cells. Blood. 1996;87(7):2665-2674.

438. Scott CL, Hughes DA, Cary D, Nicola NA, Begley CG, Robb L. Functional analysis of mature hematopoietic cells from mice lacking the betac chain of the granulocyte-macrophage colony-stimulating factor receptor. Blood. 1998;92(11):4119-4127.

439. Scott CL, Robb L, Papaevangeliou B, Mansfield R, Nicola NA, Begley CG. Reassessment of interactions between hematopoietic receptors using common beta-chain and interleukin-3-specific receptor beta-chain-null cells: no evidence of functional interactions with receptors for erythropoietin, granulocyte colony-stimulating factor, or stem cell factor. Blood. 2000;96(4):1588-1590.

440. Mittelman M, Neumann D, Peled A, Kanter P, Haran-Ghera N. Erythropoietin induces tumor regression and antitumor immune responses in murine myeloma models. Proc Natl Acad Sci U S A. 2001;98(9):5181-5186.

441. Mittelman M. The implications of anemia in multiple myeloma. Clin Lymphoma. 2003;4 Suppl 1:S23-S29.

442. Stuben $\mathrm{G}$, Thews O, Pottgen C, et al. Impact of anemia prevention by recombinant human erythropoietin on the sensitivity of xenografted glioblastomas to fractionated irradiation. Strahlenther Onkol. 2003; 179(9):620-625.

443. Sigounas G, Sallah S, Sigounas VY. Erythropoietin modulates the anticancer activity of chemotherapeutic drugs in a murine lung cancer model. Cancer Lett. 2004;214(2):171-179.

444. Thews O, Koenig R, Kelleher DK, Kutzner J, Vaupel P. Enhanced radiosensitivity in experimental tumours following erythropoietin treatment of chemotherapy-induced anaemia. Br J Cancer. 1998; 78(6):752-756

445. Silver DF, Piver MS. Effects of recombinant human erythropoietin on the antitumor effect of cisplatin in SCID mice bearing human ovarian cancer: a possible oxygen effect. Gynecol Oncol. 1999;73(2):280-284.

446. Stuben G, Thews O, Pottgen C, Knuhmann K, Vaupel P, Stuschke M. Recombinant human erythropoietin increases the radiosensitivity of xenografted human tumours in anaemic nude mice. J Cancer Res Clin Oncol. 2001;127(6):346-350.

Biologics: Targets \& Therapy

\section{Publish your work in this journal}

Biologics: Targets \& Therapy is an international, peer-reviewed journal focusing on the patho-physiological rationale for and clinical application of Biologic agents in the management of autoimmune diseases, cancers or other pathologies where a molecular target can be identified This journal is indexed on PubMed Central, CAS, EMBase, Scopus
447. Thews O, Kelleher DK, Vaupel P. Erythropoietin restores the anemiainduced reduction in cyclophosphamide cytotoxicity in rat tumors. Cancer Res. 2001;61(4):1358-1361.

448. Golab J, Olszewska D, Mroz P, et al. Erythropoietin restores the antitumor effectiveness of photodynamic therapy in mice with chemotherapy-induced anemia. Clin Cancer Res. 2002;8(5):1265-1270.

449. Tovari J, Gilly R, Raso E, et al. Recombinant human erythropoietin alpha targets intratumoral blood vessels, improving chemotherapy in human xenograft models. Cancer Res. 2005;65(16):7186-7193.

450. Lovey J, Bereczky B, Gilly R, et al. Recombinant human erythropoietin alpha improves the efficacy of radiotherapy of a human tumor xenograft, affecting tumor cells and microvessels. Strahlenther Onkol. 2008;184(1):1-7.

451. Golab J, Zagozdzon R, Stoklosa T, Jakobisiak M, Pojda Z, Machaj E. Erythropoietin prevents the development of interleukin-12-induced anemia and thrombocytopenia but does not decrease its antitumor activity in mice. Blood. 1998;91(11):4387-4388

452. Blackwell KL, Kirkpatrick JP, Snyder SA, et al. Human recombinant erythropoietin significantly improves tumor oxygenation independent of its effects on hemoglobin. Cancer Res. 2003;63(19):6162-6165.

453. Bianchi R, Gilardini A, Rodriguez-Menendez V, et al. Cisplatininduced peripheral neuropathy: neuroprotection by erythropoietin without affecting tumour growth. Eur J Cancer. 2007;43(4): 710-717.

454. Kelleher DK, Mattheinsen U, Thews O, Vaupel P. Blood flow, oxygenation, and bioenergetic status of tumors after erythropoietin treatment in normal and anemic rats. Cancer Res. 1996;56(20): 4728-4734.

455. Kirkpatrick JP, Hardee ME, Snyder SA, et al. The effect of darbepoetin alfa on growth, oxygenation and radioresponsiveness of a breast adenocarcinoma. Radiat Res. 2006;165(2):192-201.

456. van Halteren HK, Bongaerts GP, Verhagen CA, et al. Recombinant human erythropoietin attenuates weight loss in a murine cancer cachexia model. J Cancer Res Clin Oncol. 2004;130(4):211-216.

457. Hardee ME, Rabbani ZN, Arcasoy MO, et al. Erythropoietin inhibits apoptosis in breast cancer cells via an Akt-dependent pathway without modulating in vivo chemosensitivity. Mol Cancer Ther. 2006;5(2): 356-361.

458. Kjellen E, Sasaki Y, Kjellstrom J, Zackrisson B, Wennerberg J. Recombinant erythropoietin beta enhances growth of xenografted human squamous cell carcinoma of the head and neck after surgical trauma. Acta Otolaryngol. 2006;126(5):545-547.

459. Okazaki T, Ebihara S, Asada M, Yamanda S, Niu K, Arai H. Erythropoietin promotes the growth of tumors lacking its receptor and decreases survival of tumor-bearing mice by enhancing angiogenesis. Neoplasia. 2008;10(9):932-939.

460. Rupertus K, Sperling J, Corsten M, et al. Darbepoetin-alpha enhances hepatectomy-associated stimulation of colorectal liver metastatic growth. Ann Surg. 2010;252(1):131-141.

461. Mirabelli P, Di NR, Lo PC, et al. Extended flow cytometry characterization of normal bone marrow progenitor cells by simultaneous detection of aldehyde dehydrogenase and early hematopoietic antigens: implication for erythroid differentiation studies. BMC Physiol. 2008;8:13.

462. Komatsu N, Yamamoto M, Fujita H, et al. Establishment and characterization of an erythropoietin-dependent subline, UT-7/Epo, derived from human leukemia cell line, UT-7. Blood. 1993;82(2): 456-464.

\section{Dovepress}

and the Elsevier Bibliographic databases. The manuscript management system is completely online and includes a very quick and fair peerreview system, which is all easy to use. Visit http://www.dovepress. com/testimonials.php to read real quotes from published authors. 